\title{
Paleoclimate of the Kimmeridgian/Tithonian (Late Jurassic) world: II. Sensitivity tests comparing three different paleotopographic settings
}

\author{
George T. Moore ${ }^{\mathrm{a}}$, Lisa Cirbus Sloan ${ }^{\mathrm{b}}$, Darryl N. Hayashida ${ }^{\mathrm{a}}$ and Natasha P. Umrigar ${ }^{\mathrm{a}}$ \\ ${ }^{a}$ Chevron Oil Field Research Company, La Habra, CA, USA \\ ${ }^{\mathrm{b}}$ University of Michigan, Ann Arbor, MI, USA
}

(Received December 3, 1991; revised and accepted March 14, 1992)

\begin{abstract}
Moore, G.T., Sloan, L.C., Hayashida, D.N. and Umrigar, N.P., 1992. Paleoclimate of the Kimmeridgian/Tithonian (Late Jurassic) world: II. Sensitivity tests comparing three different paleotopographic settings. Palaeogeogr., Palaeoclimatol., Palaeoecol., 95: 229-252.

Topography and location of continents largely determine present-day climate. We conclude that in the geologic past paleotopographic expression was equally important. However, in the geologic record paleotopography is difficult to assess and compile because it is largely a self-destructive environment without record and is rarely addressed in the literature. An objective of this study is to test the sensitivity of paleoclimate to paleotopography by comparing three different Late Jurassic scenarios.

Paleotopography influences many paleoclimate parameters to varying degrees. To test the sensitivity of paleoclimate to modeled paleotopography for simulations incorporating a Late Jurassic reconstruction, we ran three simulations using the same boundary conditions of paleogeography (land and ocean) and atmospheric $\mathrm{CO}_{2}$ concentration, $4 x$ the pre-Industrial level $(1120 \mathrm{ppm})$. One simulation contained mountain ranges of variable height to $3 \mathrm{~km}$. In another, all the mountain ranges were reduced to $1 \mathrm{~km}$ highlands. The third simulation used a constant $500 \mathrm{~m}$ height for all land grid cells.

The sensitivity tests indicate that paleotopography is an important boundary condition. Without realistic paleotopography, flat or idealized continents surrounded by bodies of water do not produce realistic paleoclimate results. We conclude that in paleogeographic reconstructions the location and extent of mountain ranges and highlands should be recognized and given suitable elevations consistent with their plate tectonic origins, settings, and geologic ages.
\end{abstract}

\section{Introduction}

The Late Jurassic, particularly the Kimmeridgian and Tithonian (154.7-145.6 Ma) (Harland et al., 1990), were significant stages of the Mesozoic Era for several reasons. First, the time represented the important interval of Pangea's tectonic disintegration by the formation of new and the reestablishment of ancient seaway connections (Fig. 1). North America completed its separation from Gondwana, and Gondwana was split into a northern and southern continent by the rift system opening the proto-Indian Ocean. By the late

Correspondence to: G.T. Moore, Chevron Oil Field Research Company, La Habra, California.
Tithonian, two connections were established between the Tethys Sea and the Panthalassa Ocean (Ross et al., 1992). Second, the Triassic-Jurassic high sea level stand occurs within this interval. Third, Upper Jurassic rocks contain immense, economically important deposits including petroleum source rocks, reserves of oil and gas, coal, and evaporites. Finally, paleoclimate modeling of this epoch has not been attempted previously with a general circulation model (GCM).

Modeling of this interval and correlation with paleoclimatically-sensitive sedimentary rocks confirms that the Late Jurassic was a time of high $\mathrm{CO}_{2}$ (Budyko et al., 1985; Berner, 1990) and an elevated greenhouse effect (Hallam, 1985; Moore et al., 1992). In this study, we used $1120 \mathrm{ppm} \mathrm{CO}_{2}, 4 \times$ 


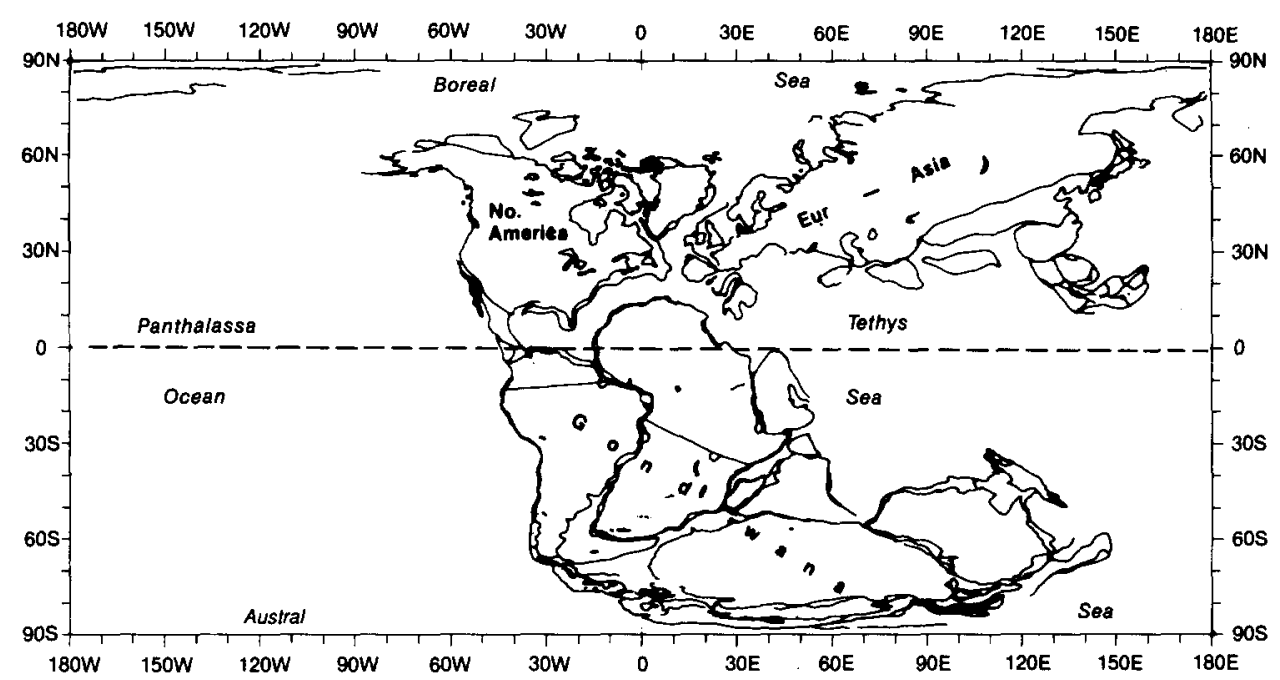

Fig. 1. Late Jurassic (Kimmeridgian/Tithonian; 154.7-145.6 Ma) paleogeography showing modern shorelines. Reconstruction based on Rowley (1992).

the pre-Industrial level of $280 \mathrm{ppm} \mathrm{CO}$ (Pearman et al., 1986; Barnola et al., 1987; Kuo et al., 1990).

Paleotopography is an important boundary condition for GCMs. There have been several climate modeling studies, which address the sensitivity of climate to topographic variations, and all agree on the importance of incorporating mountains into model boundary conditions (e.g. Kasahara and Washington, 1971; Manabe and Terpstra, 1974; Barron and Washington, 1984; Kutzbach et al., 1989; Ruddiman and Kutzbach, 1989; Sloan and Barron, 1992a). These investigations indicate that orographic influence changes with latitude, season, continental distribution, and topographic expression.

Most prior paleotopographic studies considered present day or late Cenozoic changes in mountain elevations. Because of the nature of current geography and topographic expression, these cases dealt primarily with climatic sensitivity to topographic changes in the Northern Hemisphere. The study presented here is different from those listed above in two major ways. First, we explore paleoclimate sensitivity to paleotopography in the Late Jurassic. Second, the range of topographic changes considered here includes substantial variations in the paleotopography of both hemispheres.

The purpose of this study is to evaluate three different paleotopographic scenarios and how they influence various model-generated paleoclimate parameters. The first scenario we term "variable", with mountain ranges extending to elevations of $3 \mathrm{~km}$. The heights are based on the plate tectonic settings of the mountain ranges and the range of present-day elevations in similar settings. In the second simulation we set all the mountain ranges at a $1 \mathrm{~km}$ height. We term this case " $1 \mathrm{~km}$ highlands". In the third simulation, all the continents and islands are at $500 \mathrm{~m}$ with no topographic variation. We refer to this case as "500 m plateaus".

\section{Model description}

The GCM used in this study is the National Center for Atmospheric Research's (NCAR) Community Climate Model (CCM) Version 0. It runs on a Cray X-MP at Chevron Oil Field Research Company, La Habra, California. The CCM uses thermodynamic and hydrodynamic laws applied to the atmosphere. The vertical dimension consists of nine atmospheric levels and extends through the troposphere into the middle stratosphere. The horizontal dimension consists of 40 latitude by 48 longitude grid points with each grid cell having an approximate resolution of $4.5^{\circ}$ latitude by $7.5^{\circ}$ longitude.

Moore et al. (1992) examine the simulated paleo- 
climate of the Late Jurassic world with variable paleotopography. They describe the evolution of the model and give pertinent characteristics of the CCM. Hereafter, Moore et al., (1992) will be referred to as "Part I". In this study we use a solar constant value of $1370 \mathrm{~W} \mathrm{m-2}$ and a global $\mathrm{CO}_{2}$ concentration of $1120 \mathrm{ppm}$. The bases for choosing these values are detailed in Part $I$.

These simulations employ a seasonal model in which solar insolation varies throughout the year. The atmosphere is coupled thermally but not dynamically to a mixed layer ocean, $50 \mathrm{~m}$ deep, with $5^{\circ} \times 5^{\circ}$ surface resolution (Washington and Meehl, 1984). Sea surface temperature (SST) and sea ice extent are computed as a function of the surface energy balance. Sea ice forms when the SST falls below $-1.8^{\circ} \mathrm{C}$. The deeper ocean is external to the model. The lack of dynamic coupling has obvious model-induced limitations on oceanic heat transport and related atmospheric feedbacks.

\section{Kimmeridgian/Tithonian physical world and CCM boundary conditions}

\section{Paleogeography}

Three major rift systems produced oceanic seaways that separated Pangea into major continental segments: North America, Eur-Asia, and Gondwana (Fig. 1). The compound Gondwana continent was subdivided further into north and south. The paleogeography used for these simulations shows the ocean-continent relationships at the beginning of the Kimmeridgian (middle Late Jurassic). This reconstruction was used as the oceanland input boundary conditions for the paleoclimate simulations (Fig. 2). For further details regarding the paleogeographic setting and rationale the reader is referred to Part I. This paleogeography is the same for all three cases of the current study.

\section{Paleotopography}

The CCM requires elevation to be specified for grid points designated as land. Little qualitative or quantitative elevation information is available, so we used a deductive approach to reconstruct the paleotopography. The distribution of "mountains" existing in the latest Jurassic was taken from Ziegler et al. (1983) and modified with respect to the Late Jurassic plate tectonic framework (Rowley, 1992; Scotese, 1992). We assigned values in one kilometer intervals (up to $3 \mathrm{~km}$ ) to elevated land grid points using present topographic analogues occurring in equivalent plate tectonic settings as a model (the "variable" case). Nonmountain land cells are $500 \mathrm{~m}$ high. For the case of the " $1 \mathrm{~km}$ highlands" we reduced all the mountains to a one km height. For the "500 m plateaus" case, all land grid cells are assigned that elevation.

The distribution and elevation of the mountain ranges used in the simulations are shown in Fig. 2. The northern hemisphere mountain ranges consist of the meridionally oriented Sierra Nevada and the NE-trending, rejuvenated Appalachians bordering the western and eastern margins of North America, respectively. We interpret the Sierra Nevada to have elevations ranging up to $3 \mathrm{~km}$. Elevations in the Appalachians are limited to a $2 \mathrm{~km}$ maximum. The extensive eastern Asian range represents a continuous, meridionally oriented mountain system with the higher elevations exceeding $3 \mathrm{~km}$.

The southern hemisphere contains three regions of elevated topography. Western and northwestern Gondwana are rimmed by a mountain system related to doming associated with the opening of northwestern Tethys (proto-Gulf of Mexico) and subduction along the western margin of South America. We assign values up to $3 \mathrm{~km}$ for this mountain system and term it the proto-Andes. We interpret doming and formation of highlands approximately $1 \mathrm{~km}$ in elevation to occur along the southwest Tethys rift, forming the proto-Indian Ocean. The third region is of variable height along the margin of Antarctica poleward of $80^{\circ} \mathrm{S}$ and is associated with possible plate readjustment.

CCM results are plotted in the form of a rectilinear grid and all the paleoclimate maps in this study are in such a format. An overlay of the continents is made to aid the reader in locating specific geographic areas (Fig. 2). 


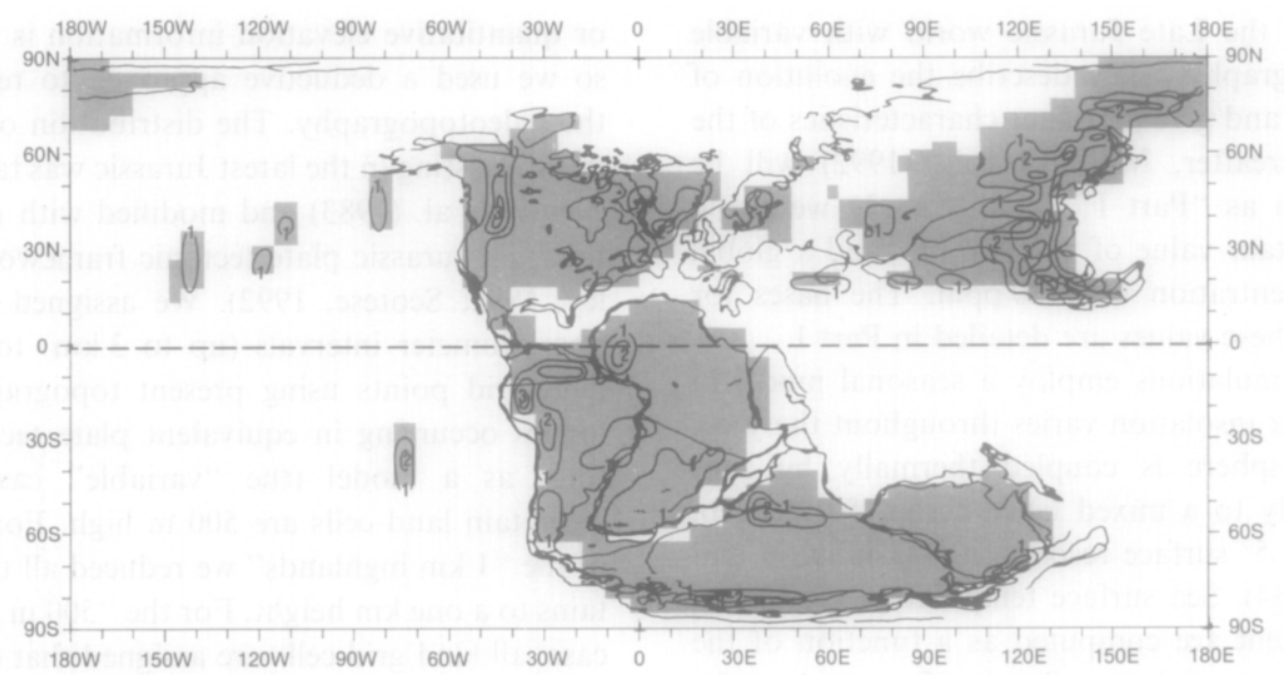

Fig. 2. Late Jurassic paleogeography at $154.7 \mathrm{Ma}$ with geologically interpreted ("variable") paleotopography (contours in km). Reconstruction based on Rowley (1992) with islands in the Panthalassa Ocean derived from Ross and Ross (1983). Continents and islands in model grid format are outlined and shaded.

\section{Paleotopography sensitivity tests}

\section{Introduction}

Topography, the location of continents, and the chemical state of the atmosphere with respect to radiative trace gases largely determine present-day climate. Bolin (1950) was one of the first to observe that the generation and location of jet streams are influenced by continental distributions and mountain range locations. Bolin (1950) also observed that planetary waves are anchored by mountains such that wave ridges are generally located over mountain crests and wave troughs are located in mountain lees. These relationships between atmospheric circulation and topography have also been simulated in several GCM studies. Manabe and Terpstra (1974) examined a present day world with and without mountains. They found that flow of the atmosphere is anchored by mountains, with stationary troughs occurring in mountain lees. Their results show that atmospheric flow is less zonal when mountains are included in model boundary conditions and that precipitation distributions vary substantially between topographic cases. Barron and Washington (1984) examined the effect of topographic definition upon both present day and Cretaceous simulated climates. In each case, addition of topography (vs. plateautype continents) resulted in a general average surface temperature decrease of $1.1^{\circ} \mathrm{C}$. Barron and Washington (1984) noted a "clear association" between areas of greatest temperature and of greatest topographic difference. Further, they noted the occurrence of direct and indirect effects of topographic variation upon climate.

Kutzbach et al. (1989) and Ruddiman and Kutzbach (1989) examined late Cenozoic uplifts in western North America and in southern Asia through a sensitivity study which incorporated three different descriptions of continental elevations. This study reiterated the general atmospheric circulation results of Manabe and Terpstra (1974) and the thermal response seen by Barron and Washington (1984), but also provided insight into possible mechanisms of late Cenozoic climatic change relating to tectonic uplift. Kutzbach et al. (1989) and Ruddiman and Kutzbach (1989) demonstrated that the expression of paleotopography was a critical factor in accurate simulations of late Cenozoic paleoclimates.

Sloan and Barron (1992a) examined the effects of two different specified elevations of the Rocky Mountains upon Eocene paleoclimate. Except for limited temperature and precipitation changes, they found little response of paleoclimate to eleva- 
tion changes for cases incorporating mountain heights of $500 \mathrm{~m}$ and $1 \mathrm{~km}$. Sloan and Barron (1992a) suggested that a critical mountain height for perturbation of atmospheric flow was not reached by this range of specified elevation. In a 1988 study, Rind found that climate simulated by the Goddard Institute for Space Studies' GCM was greatly influenced by the spatial resolution of specified paleotopography. In this case the implication is that, not only is inclusion of paleotopography important to simulated paleoclimate, but how that topography is described also may be critical.

\section{Results}

We completed three seasonal paleoclimate simulations with the same Kimmeridgian/Tithonian paleogeography and differing paleotopography. In all these cases, the CCM was initialized with isothermal conditions and run for sixteen model years. The results compared here are 90-day seasonal averages taken from model year 15.5 (June/ July/Aug; JJA) and model year 16.0 (Dec/Jan/Feb; DJF). Paleotopography is the only boundary condition that was changed between the simulations.

We analyze the results of the three simulations with varying paleotopography for overall planetary tropospheric and lower stratospheric circulation as well as for the global paleoclimatic effects at the Earth's surface. We use surface temperature, sea level pressure together with surface winds, precipitation, and latent heat to evaluate the global surface effects of modified paleotopography.

\section{Jet stream patterns and storm tracks}

As in previous GCM investigations of topography (e.g., Manabe and Terpstra, 1974), we find that increasing topographic expression produced increasingly azonal wind patterns. Beyond this result, responses to paleotopographic variations from case to case are less systematic.

The orographic effects of particularly meridionally-oriented mountain ranges in the "variable" case are manifested in the deflection of flow from a more zonal to an oblique orientation (Figs. 3 and 4 ). When all the mountain ranges are reduced to " $1 \mathrm{~km}$ highlands" the atmospheric circulation becomes more zonal, a result that is most noticeable in the winter hemispheres. This response is most enhanced for the "500 m plateaus" case. The summer patterns are more complicated by the summer jet being weaker and responding to interference by thermal contrasts between the oceans and continents. The equatorial counter flow likewise is weaker in the " $1 \mathrm{~km}$ highlands" and "500 $m$ plateaus" paleotopographic simulations than in the fully "variable" paleotopographic case.

The simplification of jet stream pathways toward more linearity from the "variable" to the " $500 \mathrm{~m}$ plateaus" case affects the position of the winter mid-latitude storm tracks. This is shown by the two extreme cases (Figs. 5 and 6). Surprisingly, intensity of the storm tracks does not change substantially between the "variable" and " $500 \mathrm{~m}$ plateaus" cases for either season. For DJF, inclusion of the fully "variable" topography produces a winter storm track which circumvents the Sierra Nevada. The mountains of the eastern Asian range at maximum height effectively disrupt continuity of the storm track. In contrast, the storm track of the " $500 \mathrm{~m}$ plateaus" case is quite zonal and more uniform in intensity. In JJA of the southern hemisphere, due to the zonal orientation of the southern Tethyan shoreline (India and Australia) at about $50^{\circ} \mathrm{S}$ and its relatively low coastal relief, the storm track is in the same position and about as strong in both simulations.

\section{Surface temperature}

Surface temperature results vary in response to changing paleotopography. The "variable" case produces more complex thermal patterns for both seasons over land in the northern hemisphere (N.H.) than the other two cases (Figs. 7 and 8). However, such a response is not as obvious in the land surface temperatures for the southern hemisphere (S.H.). The absence of this association in the S.H. may result from less paleotopographic variation than in the N.H. but also may be related to less sea ice in the S.H. to influence nearby continental temperatures (Part I). The sea surface temperature (SST) likewise becomes strongly zonal in the "1 km highlands" and "500 m plateaus" cases (Figs. 7 and 8). 


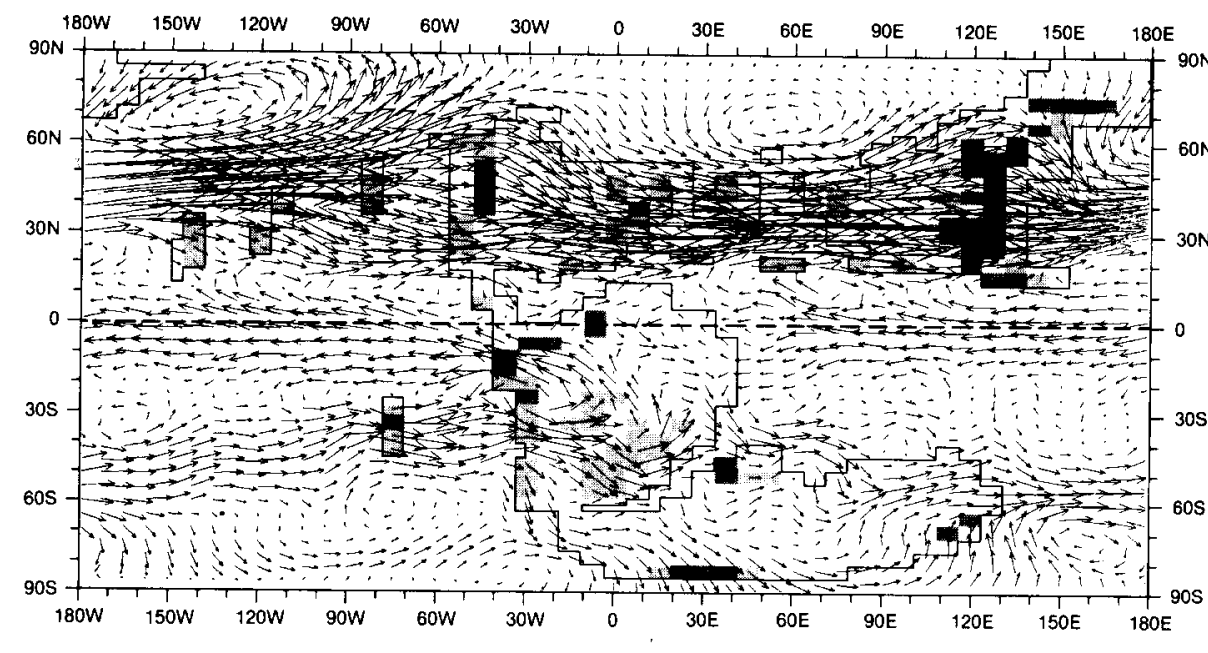

"Variable"
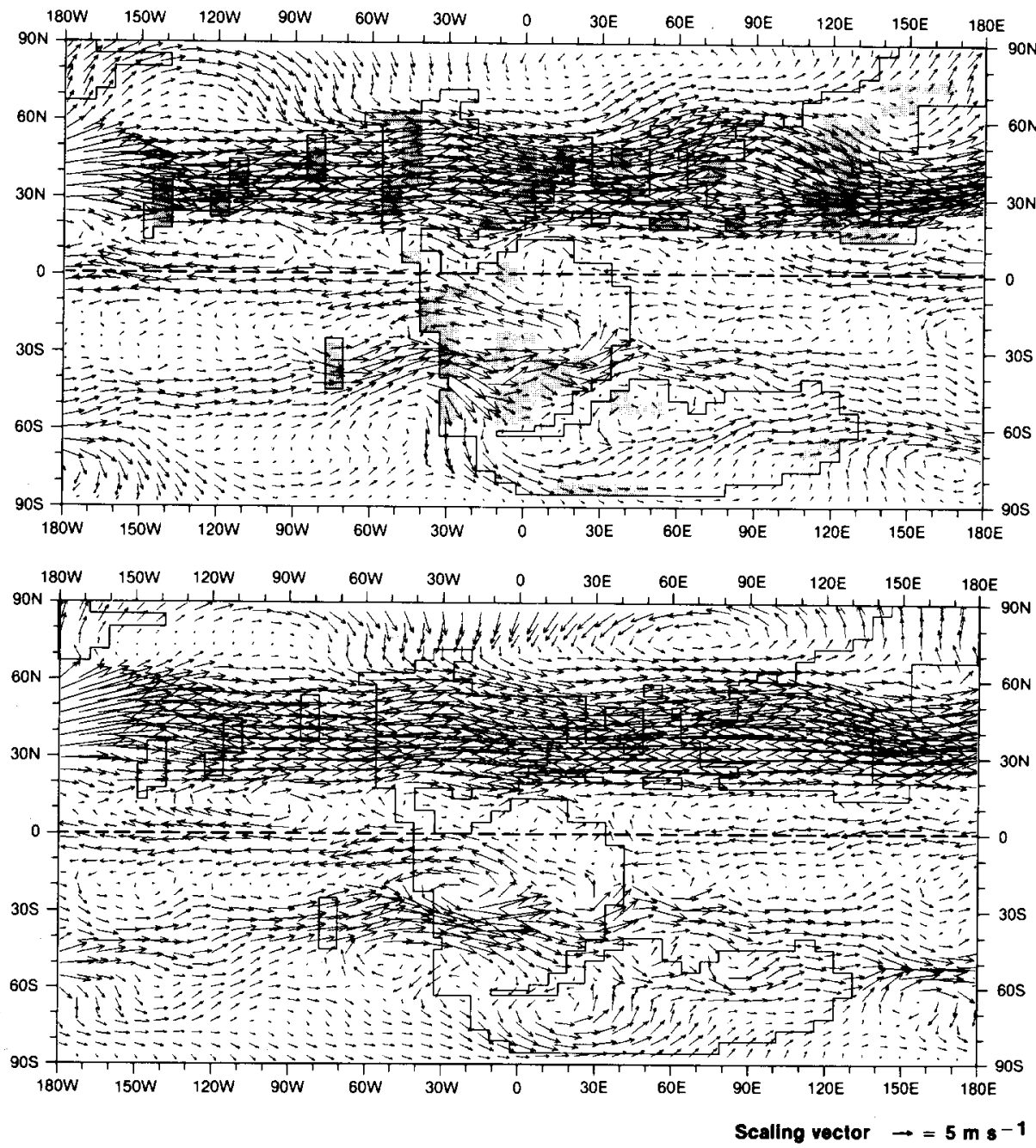

"1 km Highlands"

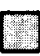

Fig. 3. Dec/Jan/Feb wind vectors at $500 \mathrm{mb}$ for three Late Jurassic, $1120 \mathrm{ppm} \mathrm{CO}_{2}$ simulations with differing paleotopography. For identification of each simulation, refer to right hand margin. Continents and islands in model grid format are outlined. In maps where appropriate, $H$ and $L$ refer to high and low values, respectively within closed contours. Dashed contours represent negative values. 


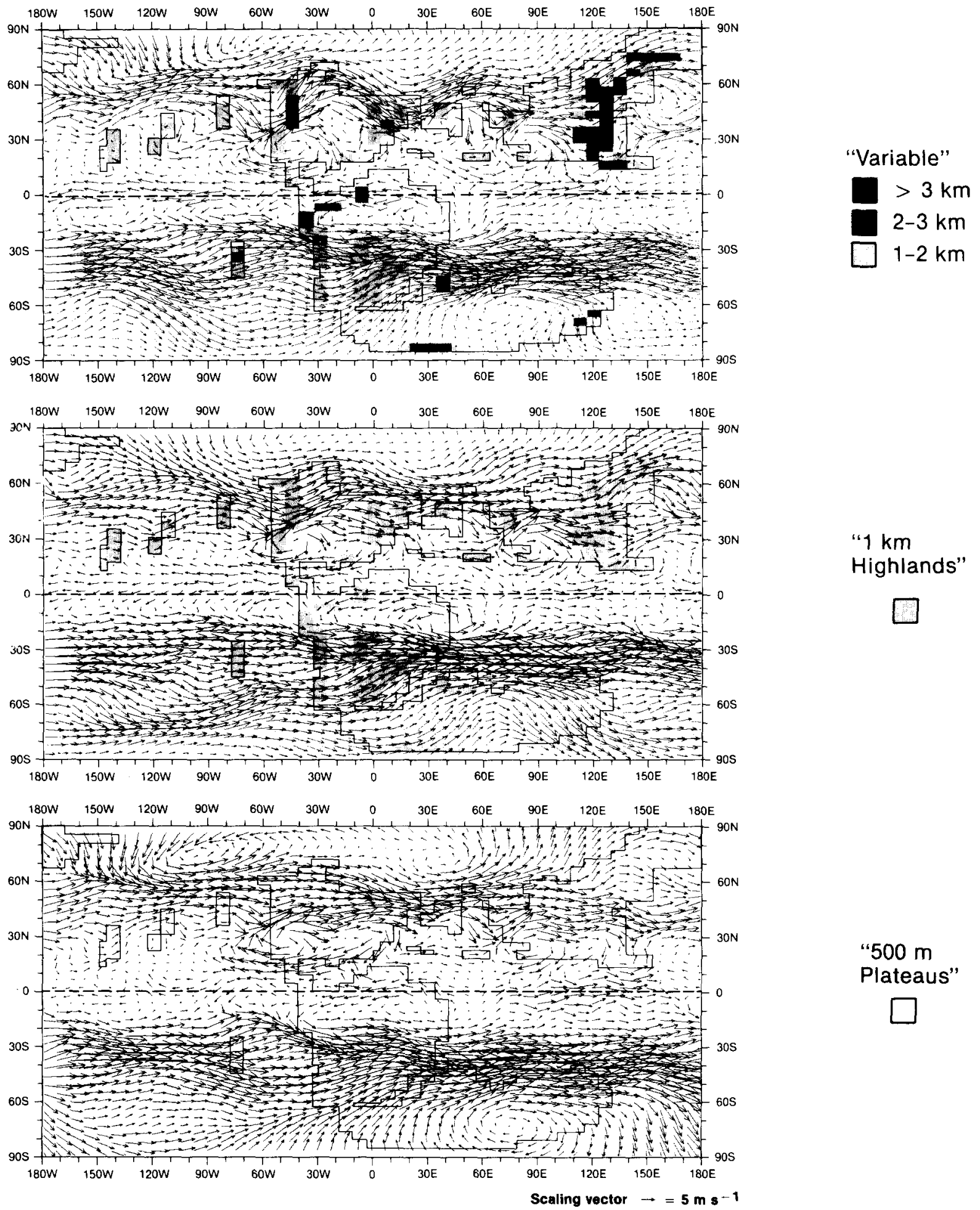

Fig. 4. June/July/Aug wind vectors at $500 \mathrm{mb}$ for three Late Jurassic $1120 \mathrm{ppm} \mathrm{CO}_{2}$ simulations with differing paleotopography. See Fig. 3 for explanation. 


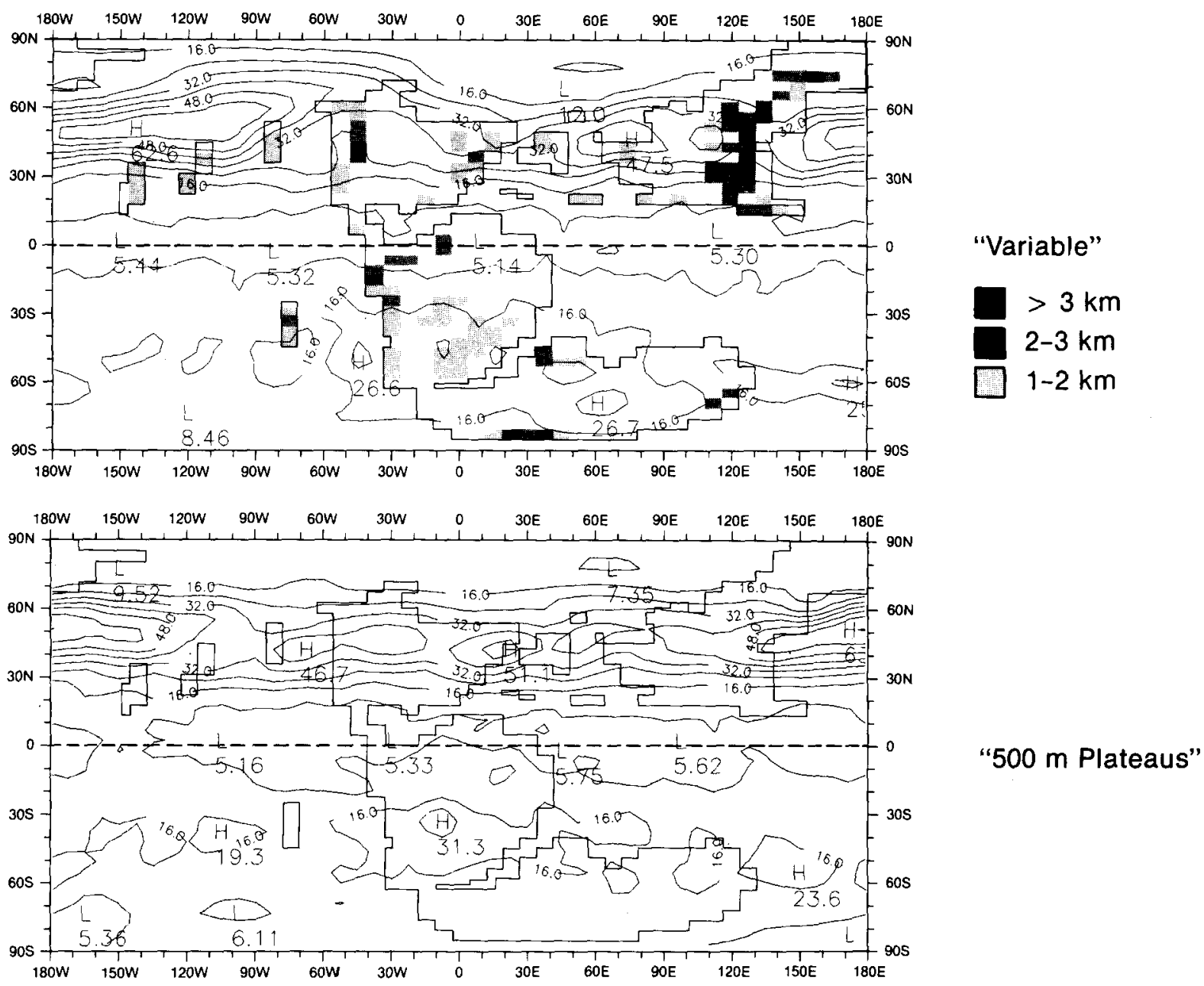

Fig. 5. Dec/Jan/Feb storm tracks from the time-filtered (2.5-6 days) standard deviation of the geopotential height field (m) at 500 $\mathrm{mb}$ in the "variable" (top) and "500 m plateaus" (bottom) cases. $\mathrm{CI}=8 \mathrm{~m}$. See Fig. 3 for explanation.

Seasonal DJF and JJA temperature difference plots are shown to highlight the regions of significant change or the lack thereof (Figs. 9 and 10). Both the " $1 \mathrm{~km}$ highlands" and " $500 \mathrm{~m}$ plateaus" cases are individually compared to and subtracted from the "variable" one, grid cell by grid cell. Positive values (solid lines) indicate that temperature values in the "variable" simulation are higher than in the subtracted case. For negative values (dashed lines) the reverse is true, the temperature values are lower in the "variable" simulation than in the subtracted case.

Maps of surface temperature differences (Figs. 9 and 10) emphasize the direct effect of paleotopography upon temperature through lapse rates;' a cooling of regions with increasing elevation, especially in the "variable" minus "500 m plateaus" comparison. The mountain ranges of the Sierra Nevada, eastern Asia, and the north end of the proto-Andes are cooler in the "variable" case in both seasons. However, the "variable" minus the "500 m plateaus" comparisons show a consistently stronger lapse rate-related cooling in the summer season of both hemispheres. Further, the difference maps indicate that areas some distance from the reduced paleotopographic contrasts experience temperature changes apparently due to certain indirect effects of the modified conditions.

The most significant global changes in the DJF temperature difference plots occur in the N.H. 


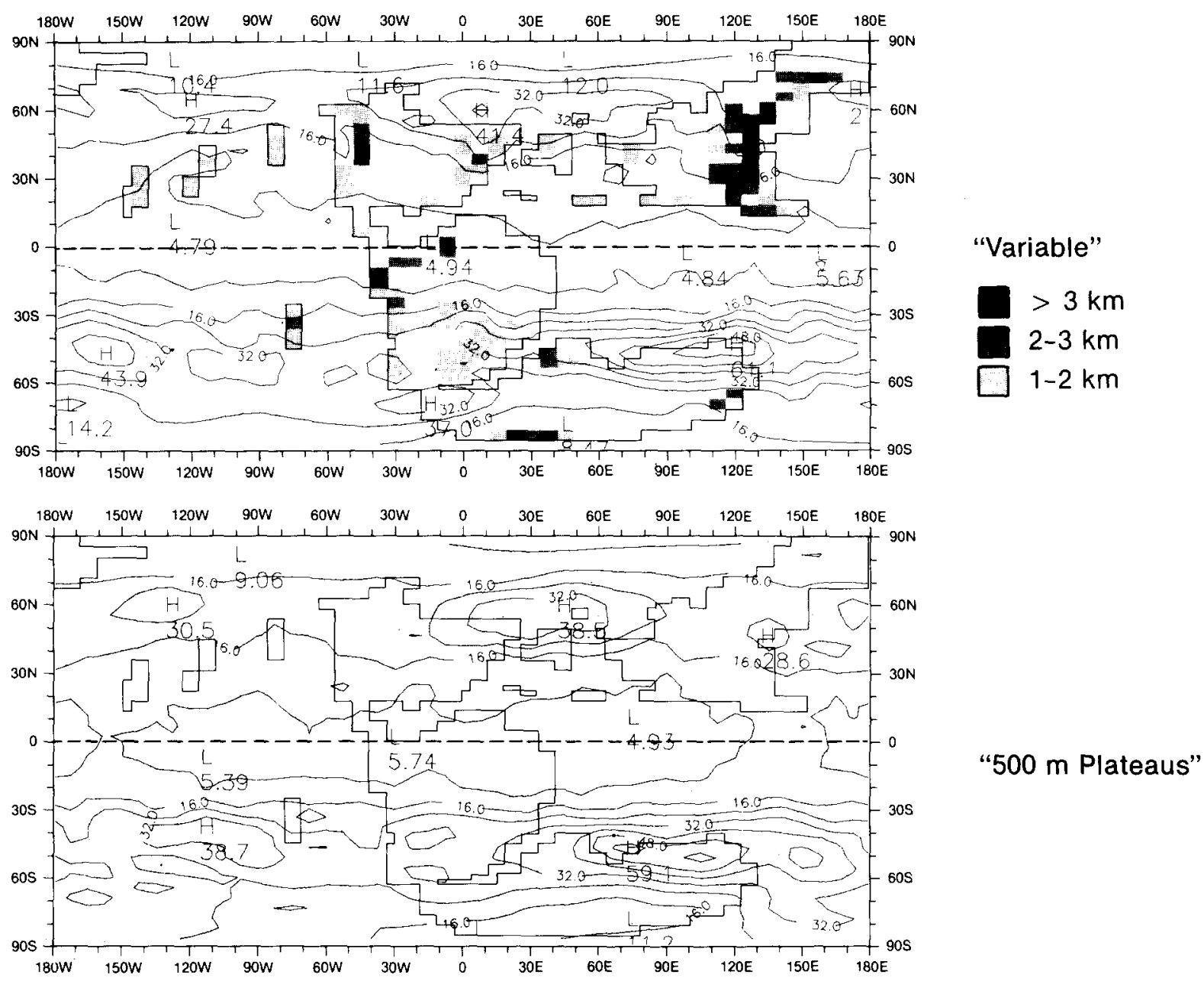

Fig. 6. June/July/Aug storm tracks from the time-filtered (2.5-6 days) standard deviation of the geopotential height field (m) at 500 $\mathrm{mb}$ between the "variable" (top) and "500 m plateaus" (bottom) cases. $\mathrm{CI}=8 \mathrm{~m}$. See Fig. 3 for explanation.

north of $50^{\circ}$ latitude (Fig. 9). The northern Panthalassa Ocean is warmed $\left(\sim 30^{\circ} \mathrm{C}\right)$ in both the " $1 \mathrm{~km}$ highlands" and " $500 \mathrm{~m}$ plateaus" cases. The Boreal Sea in the same respective cases cools near northwestern North America. In all probability, this reflects a change in hemispheric circulation caused by lowered elevations in the eastern Asia range. Otherwise the oceans show little change. Southern Asia shows strong warming (western) and cooling (eastern) trends along the margin of the Tethys Sea in the two restricted paleotopographic cases. Generally, interior Gondwana temperatures are higher in the "1 km highlands" and "500 m plateaus" cases (Fig. 9).

By comparison, the JJA temperature difference plots show the northern Panthalassa Ocean temperature changes in the " $1 \mathrm{~km}$ highlands" and "500 m plateaus" cases are about one-third that of the DJF range (Fig. 10), the most significant large scale change in the simulations. The remainder of the world ocean exhibits little change for the most part. Temperatures decrease over the eastern Asian range in the " $1 \mathrm{~km}$ highlands" and "500 m plateaus" cases when compared with the "variable" case.

\section{Sea level pressure and surface winds}

DJF and JJA sea level pressure maps for the three paleotopographic sensitivity cases are paired 


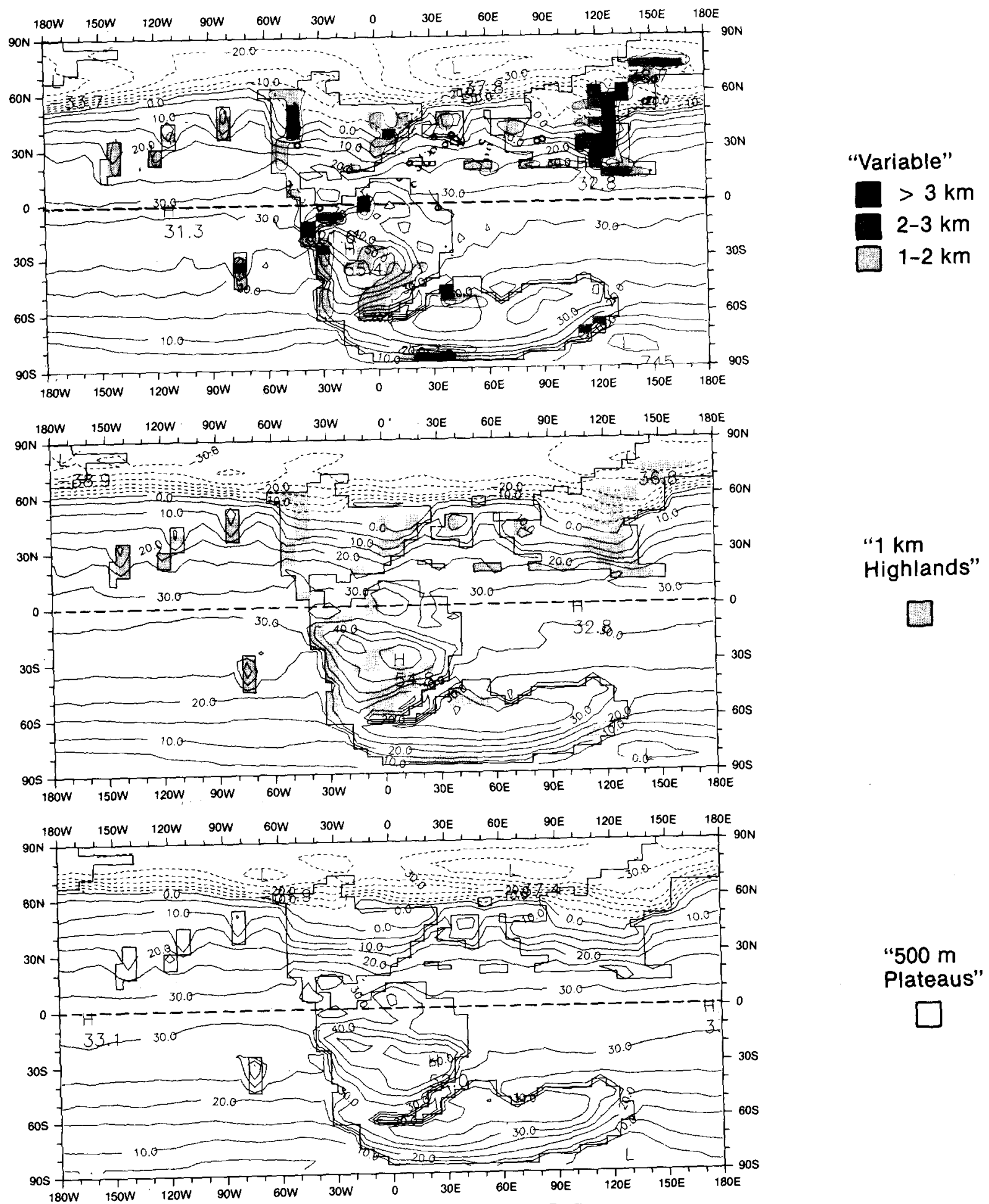

Fig. 7. Dec/Jan/Feb surface temperature $\left({ }^{\circ} \mathrm{C}\right)$ for three Late Jurassic $1120 \mathrm{ppm} \mathrm{CO}_{2}$ simulations with differing paleotopography $\mathrm{CI}=5^{\circ} \mathrm{C}$. See Fig. 3 for explanation. 

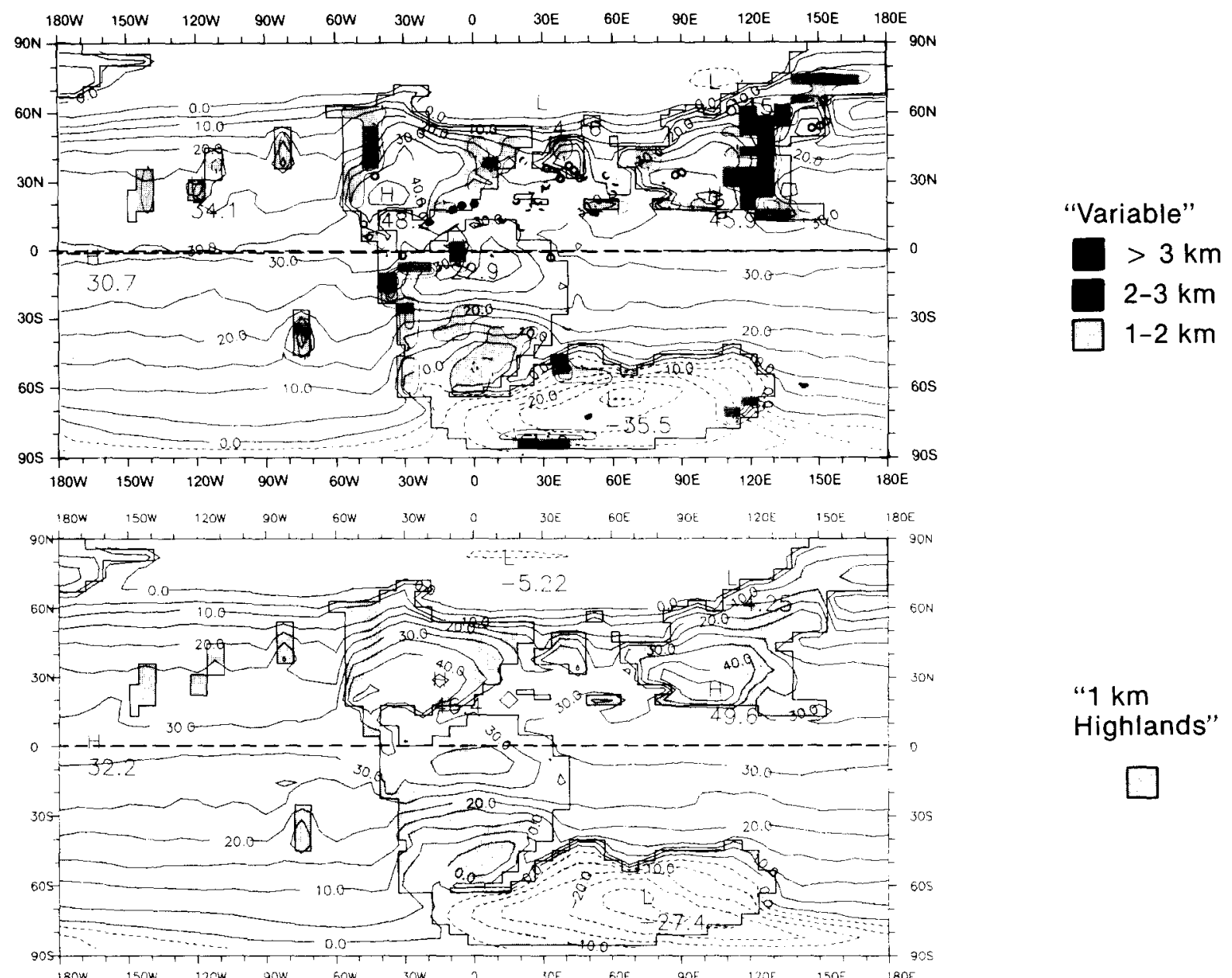

"1 km Highlands"

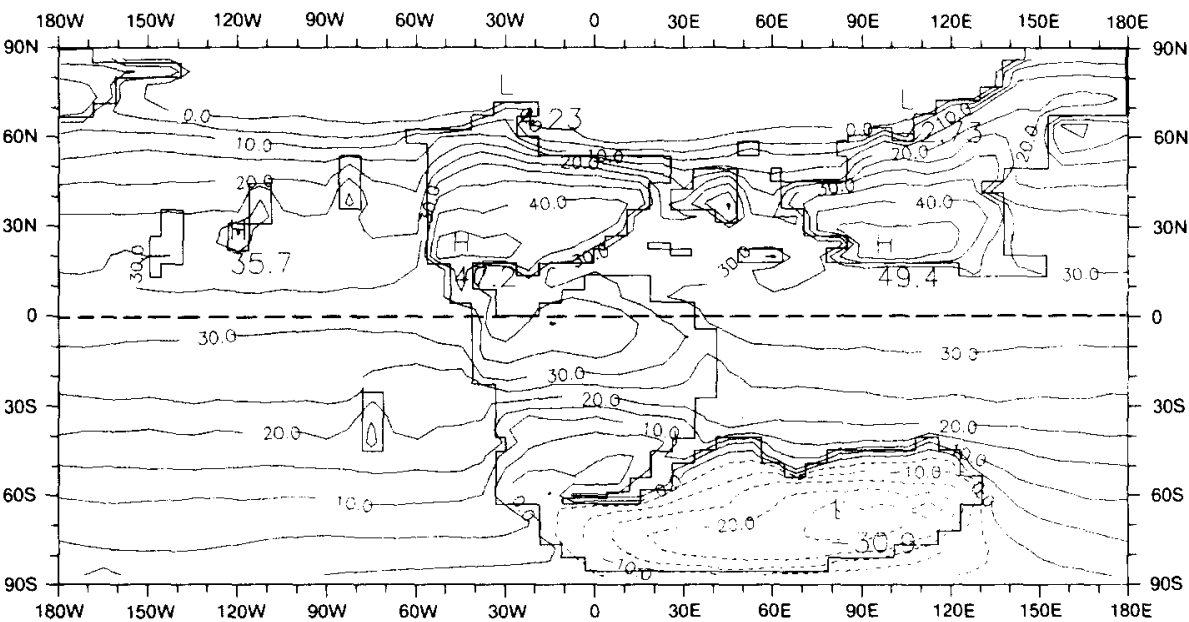

"500 m

Plateaus"

Fig. 8. June/July/Aug surface temperature (C) for three Late Jurassic $1120 \mathrm{ppm} \mathrm{CO}_{2}$ simulations with differing paleotopography. $\mathrm{CI}=5^{\circ} \mathrm{C}$. See Fig. 3 for explanation. 


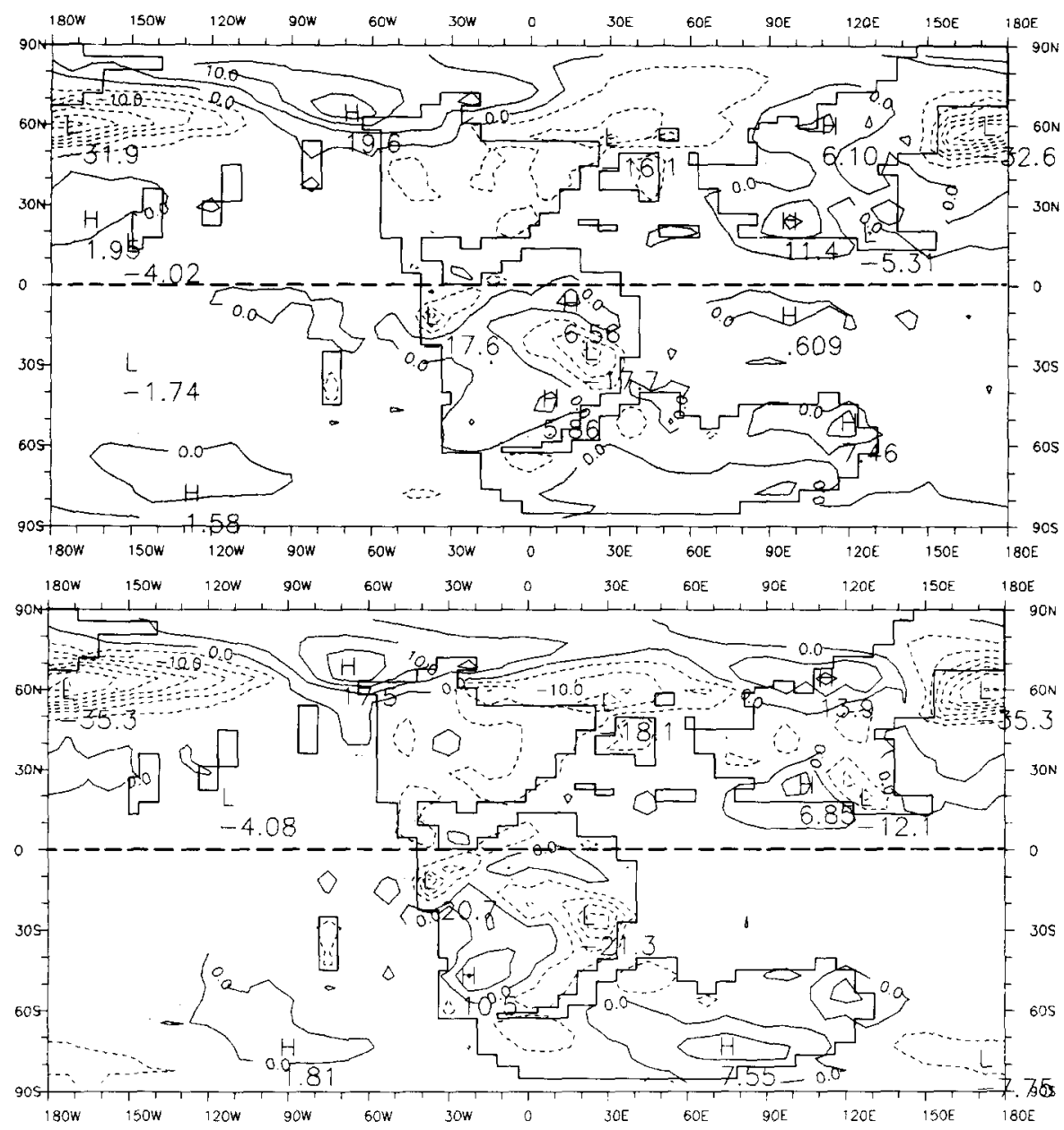

\section{"Variable" - "1 km Highlands"}

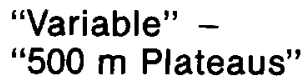

Fig. 9. Dec/Jan/Feb difference plots for surface temperature $\left({ }^{\circ} \mathrm{C}\right)$ between the "variable" minus " 1 km highlands" and "variable" minus " $500 \mathrm{~m}$ plateaus". $\mathrm{CI}=5^{\circ} \mathrm{C}$. See Fig. 3 for explanation.

with their comparable surface wind vector maps (Figs. 11 and 12, 13, 14, respectively). Sea level pressure in the "variable" simulation shows a marked difference from the other two cases. This result is mimicked by surface wind patterns. Generally, surface wind vector plots illustrate increased flow diversion with increasing paleotopographic expression and more zonal flow with flatter continents. A trend exists toward very simplified zonal circulation in each of the winter hemispheres from the "variable" to the " 500 m plateaus" simulations. This occurs despite the dissimilar paleogeographies in the hemispheres. The winter equator-to-pole temperature gradients appear stronger than any land-sea differentials (Figs. 7 and 8). In contrast, the respective hemisphere summer temperatures warm the continents sufficiently to develop and maintain continental low pressure systems versus oceanic high pressure systems in the mid-latitudes (Figs. 7 and $8 ; 11$ and 13). Thus, the summer circulation patterns in both hemispheres, while simplified, remain dominated by paleogeography, irrespective of paleotopography.

Regionally, the intense DJF low in the central part of the Boreal Sea forms a zonally-oriented low centered in the eastern ocean in the " $1 \mathrm{~km}$ highlands" and "500 m plateaus" simulations (Fig. 11). This can be directly attributed to the northward deflection of the subtropical high over the Sierra Nevada range in western North America, which constrains the low pressure system over the ocean in the "variable" case (Fig. 11). 


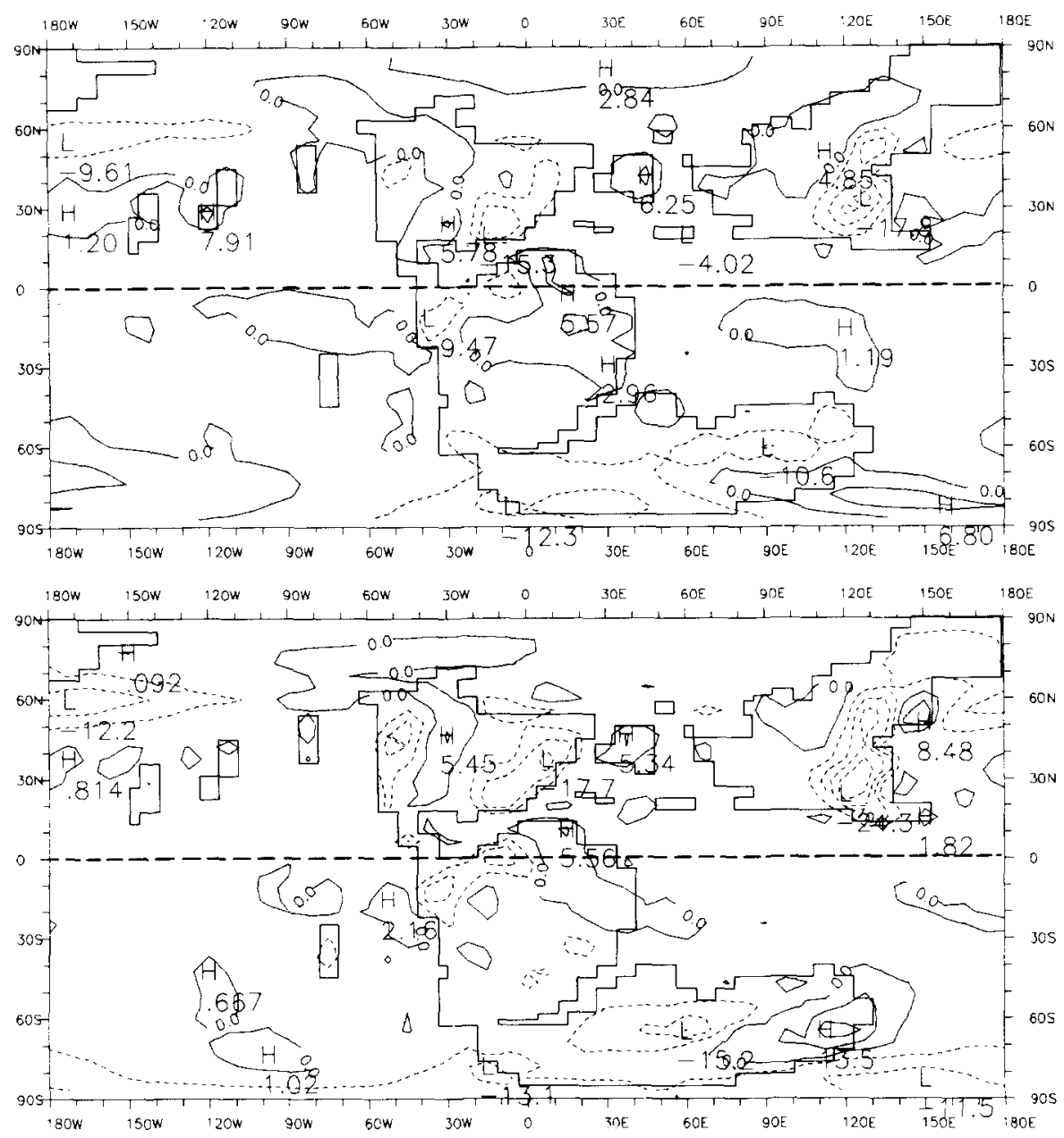

"Variable" "1 km Highlands"

\section{"Variable" - "500 m Plateaus"}

Fig. 10. June/July/Aug difference plots for surface temperature $\left({ }^{\circ} \mathrm{C}\right)$ between the "variable" minus " 1 km highlands" and "variable" minus " $500 \mathrm{~m}$ plateaus". $\mathrm{CI}=5^{\circ} \mathrm{C}$. See Fig. 3 for explanation.

The JJA pressure differential between the subtropical high over the eastern Panthalassa Ocean and the low over North America decreases in the "1 km highlands" and "500 m plateaus" simulations (Fig. 13). This causes a weakening of the northeast trade winds. The JJA deep monsoonal low and associated wind circulation over southeastern Asia progressively weakens (Figs. 13 and 14 ) in the " $1 \mathrm{~km}$ highlands" and "500 m plateaus" paleotopographic cases.

\section{Precipitation}

The location of landmasses strongly influences the distribution of precipitation belts and centers. While the main centers of tropical rainfall change among the three paleotopographic cases, overall the intensities of the centers and the regional pattern of the rainbelts are not significantly different (Figs. 15 and 16). The DJF precipitation center over northeastern Gondwana results largely from the onshore flow of marine air brought by the easterlies (Fig. 12). The wind pattern is similar for all three cases. The regionally complex center transforms to a more linear pattern where the interior highlands paralleling the proto-Indian Ocean are not present to orographically force precipitation in the "500 $\mathrm{m}$ plateaus" case (Fig. 17). Moderate rainfall associated with the Sierra Nevada is not affected significantly by the range of elevations specified for these mountains.

Precipitation patterns reflect monsoon circula- 


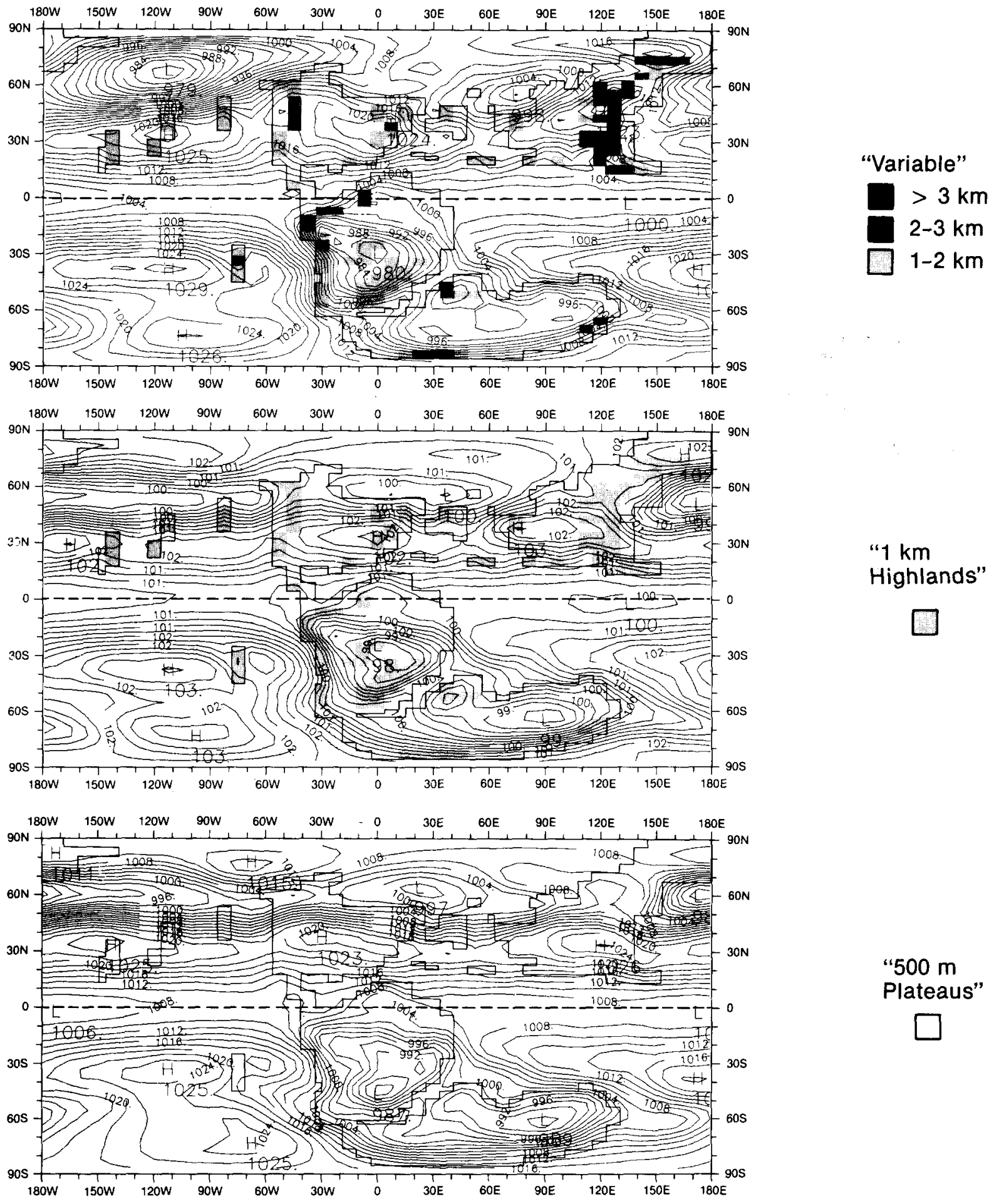

Fig. 11. Dec/Jan/Feb sea level pressure (mb) for three Late Jurassic $1120 \mathrm{ppm} \mathrm{CO}_{2}$ simulations with differing paleotopography. $\mathrm{CI}=2 \mathrm{mb}$. See Fig. 3 for explanation. 


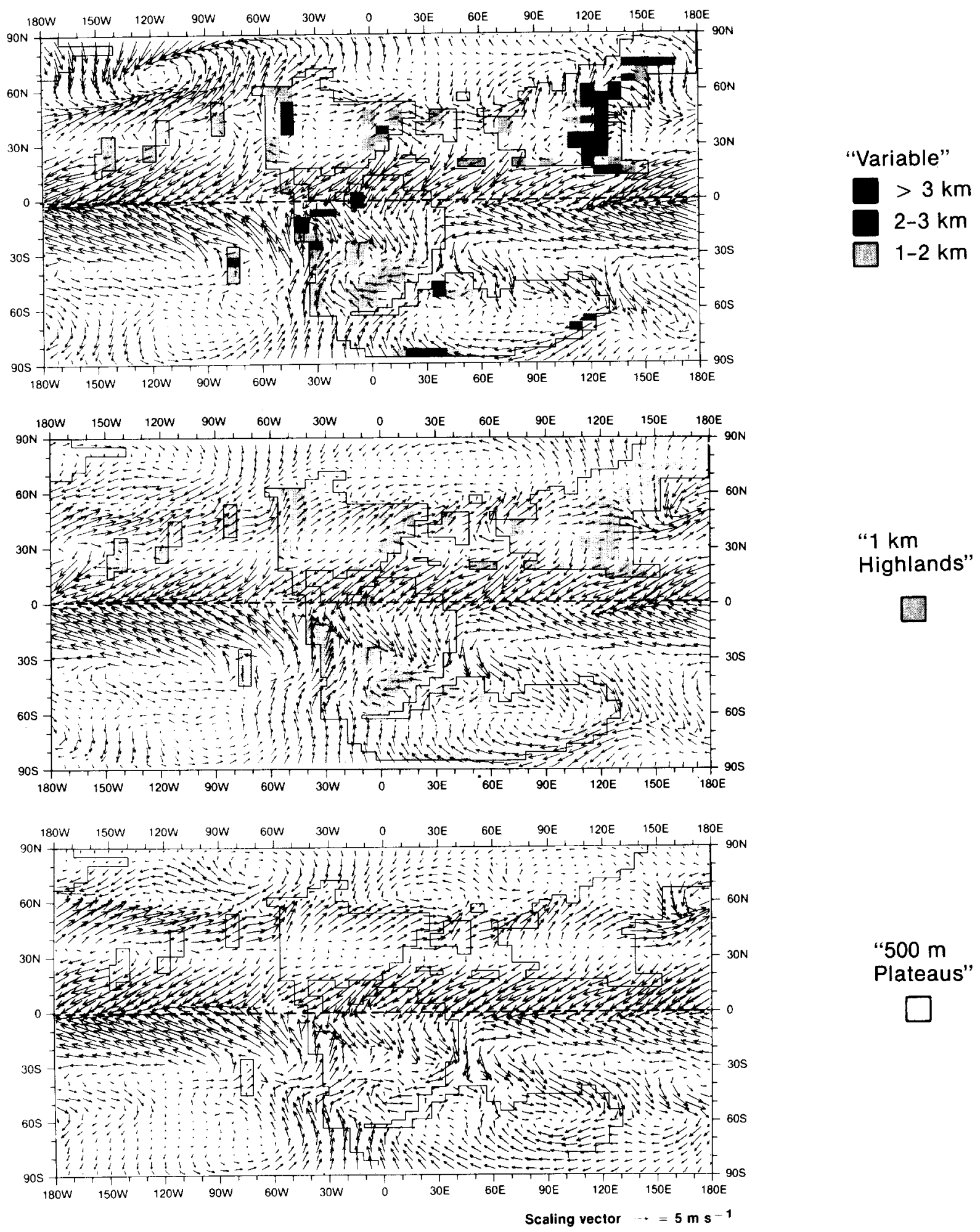

Fig. 12. Dec/Jan/Feb surface wind vectors for three Late Jurassic $1120 \mathrm{ppm} \mathrm{CO}_{2}$ simulations with differing paleotopography. See Fig. 3 for explanation. 


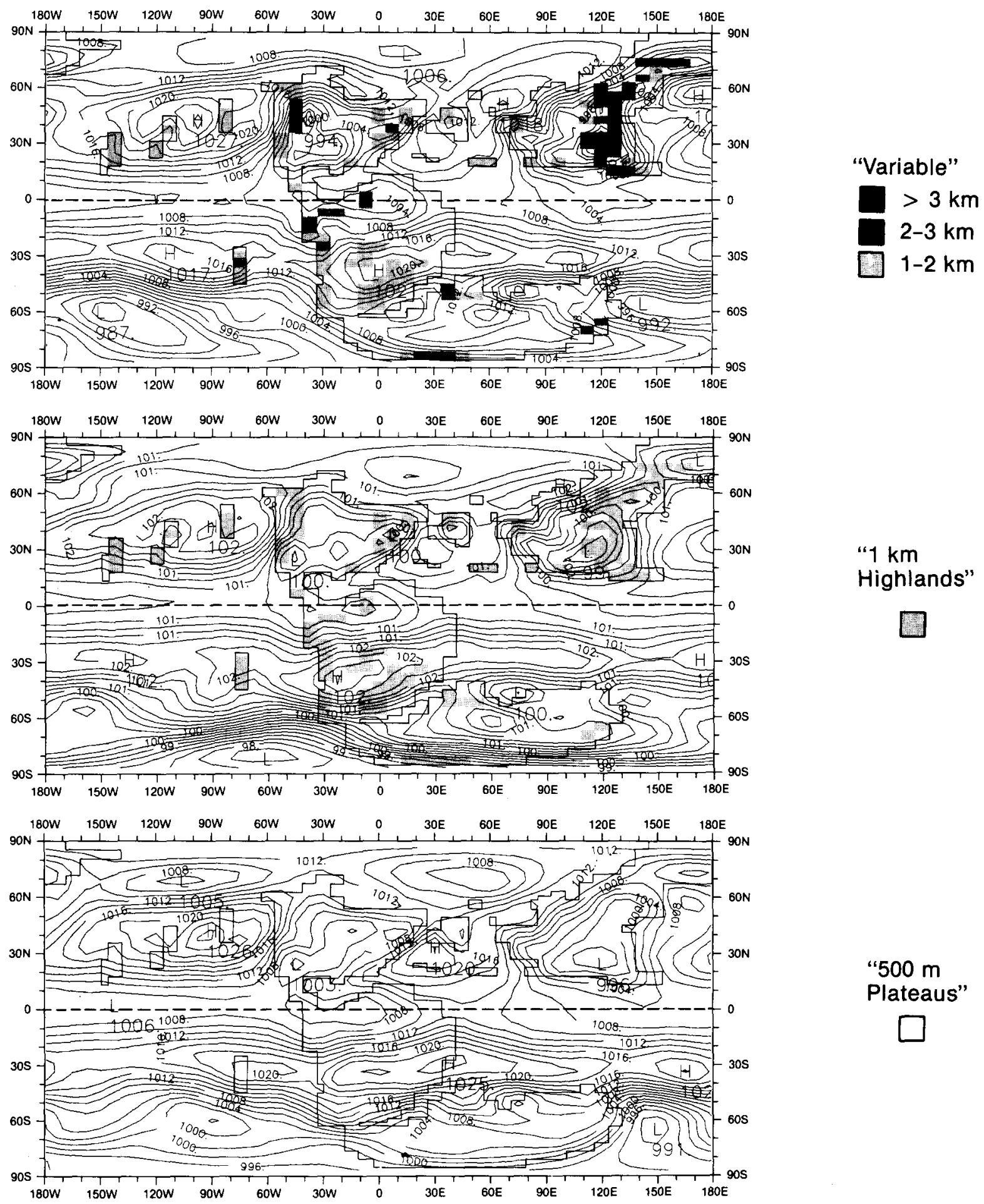

Fig. 13. June/July/Aug sea level pressure (mb) for three Late Jurassic $1120 \mathrm{ppm} \mathrm{CO}_{2}$ simulations with differing paleotopography. $\mathrm{CI}=2 \mathrm{mb}$. See Fig. 3 for explanation. 


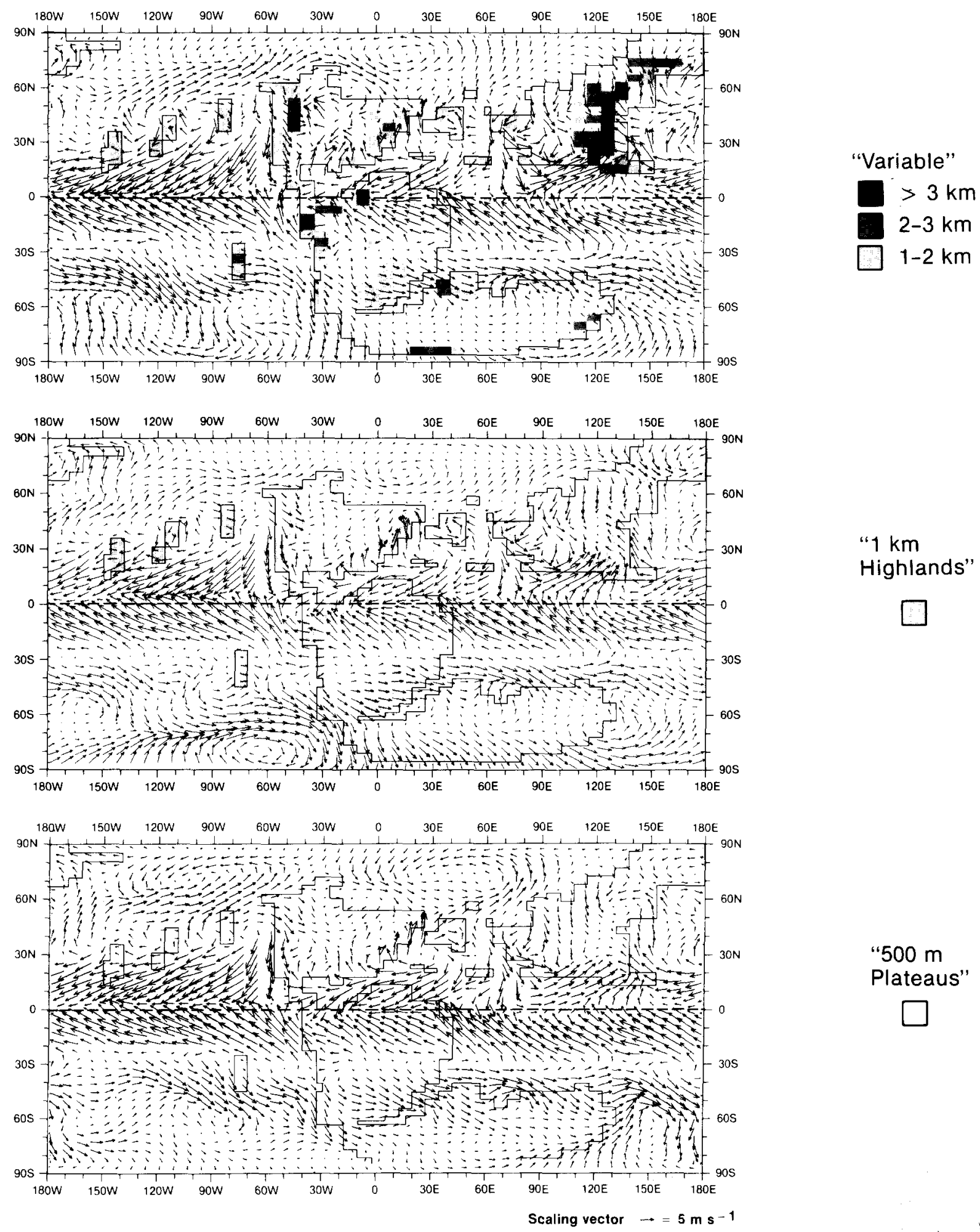

Fig. 14. June/July/Aug surface wind vectors for three Late Jurassic, $1120 \mathrm{ppm} \mathrm{CO}_{2}$ simulations with differing paleotopography. See Fig. 3 for explanation. 


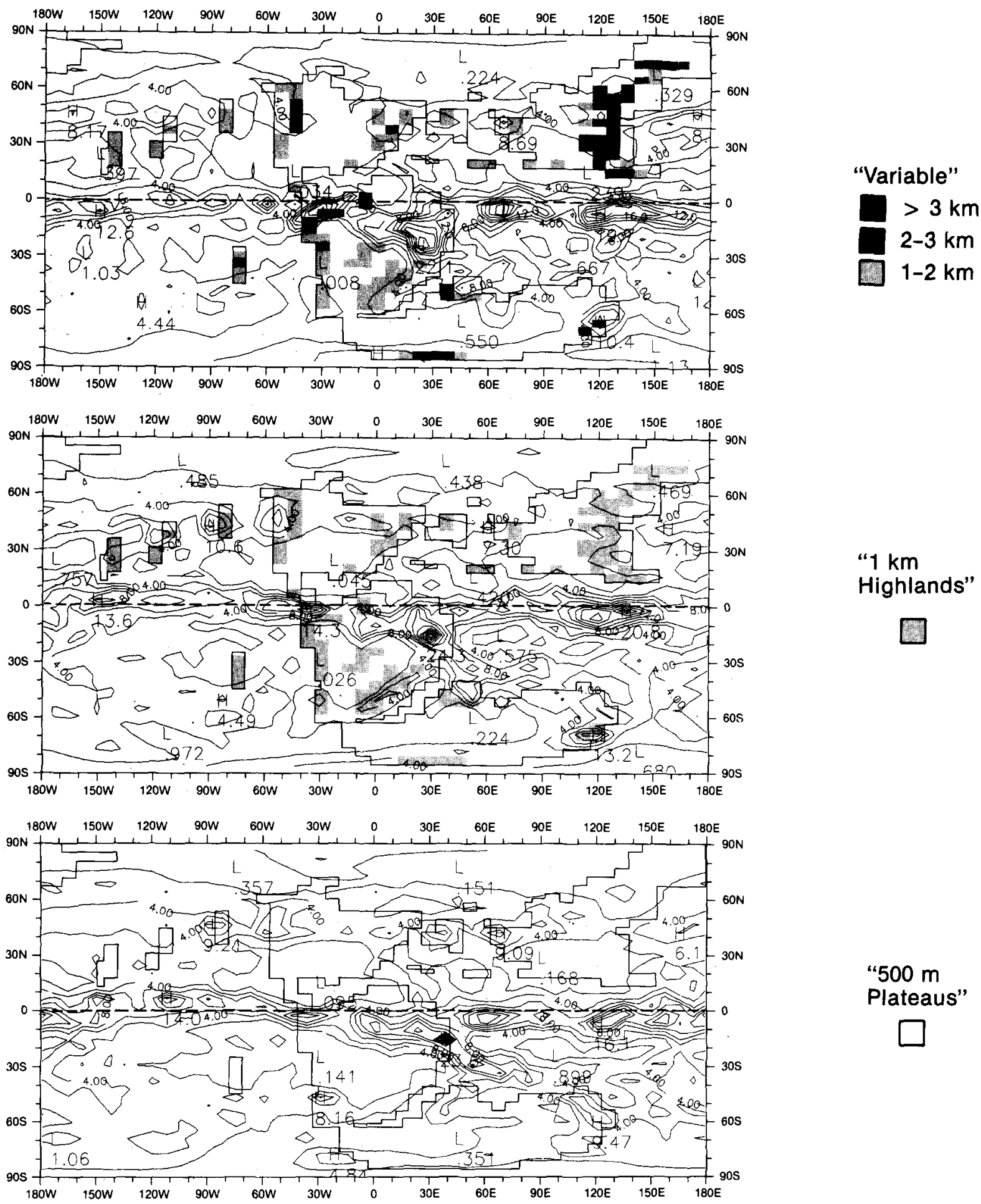

Fig. 15. Dec/Jan/Feb precipitation ( $\left.\mathrm{mm} \mathrm{d}^{-1}\right)$ for three Late Jurassic, $1120 \mathrm{ppm} \mathrm{CO}_{2}$ simulations with differing paleotopography. $\mathrm{CI}=2 \mathrm{~mm} \mathrm{~d}^{-1}$. See Fig. 3 for explanation. 


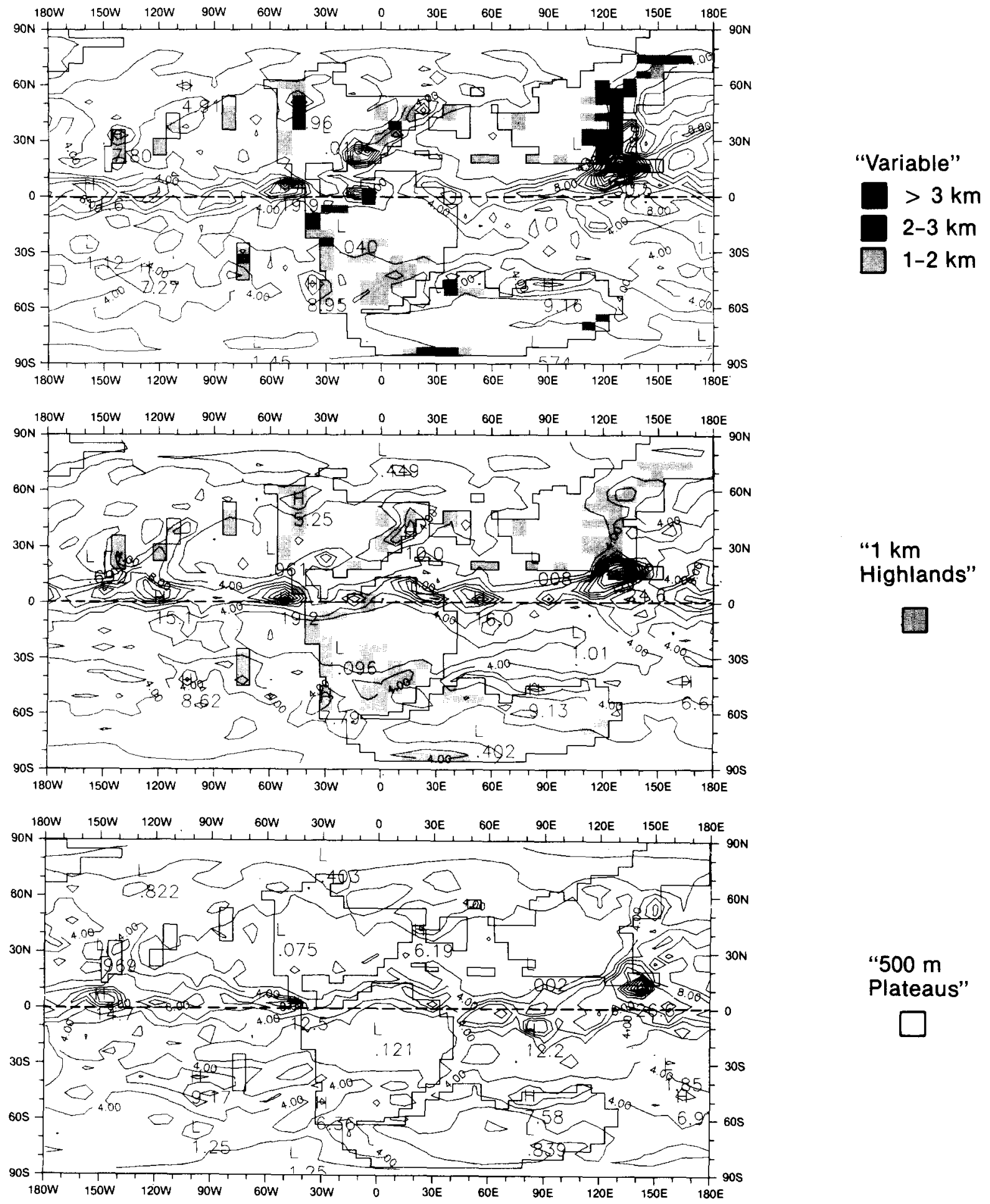

Fig. 16. June/July/Aug precipitation $\left(\mathrm{mm} \mathrm{d}^{-1}\right)$ for three Late Jurassic, $1120 \mathrm{ppm} \mathrm{CO}_{2}$ simulations with differing paleotopography. $\mathrm{CI}=2 \mathrm{~mm} \mathrm{~d}^{-1}$. See Fig. 3 for explanation. 


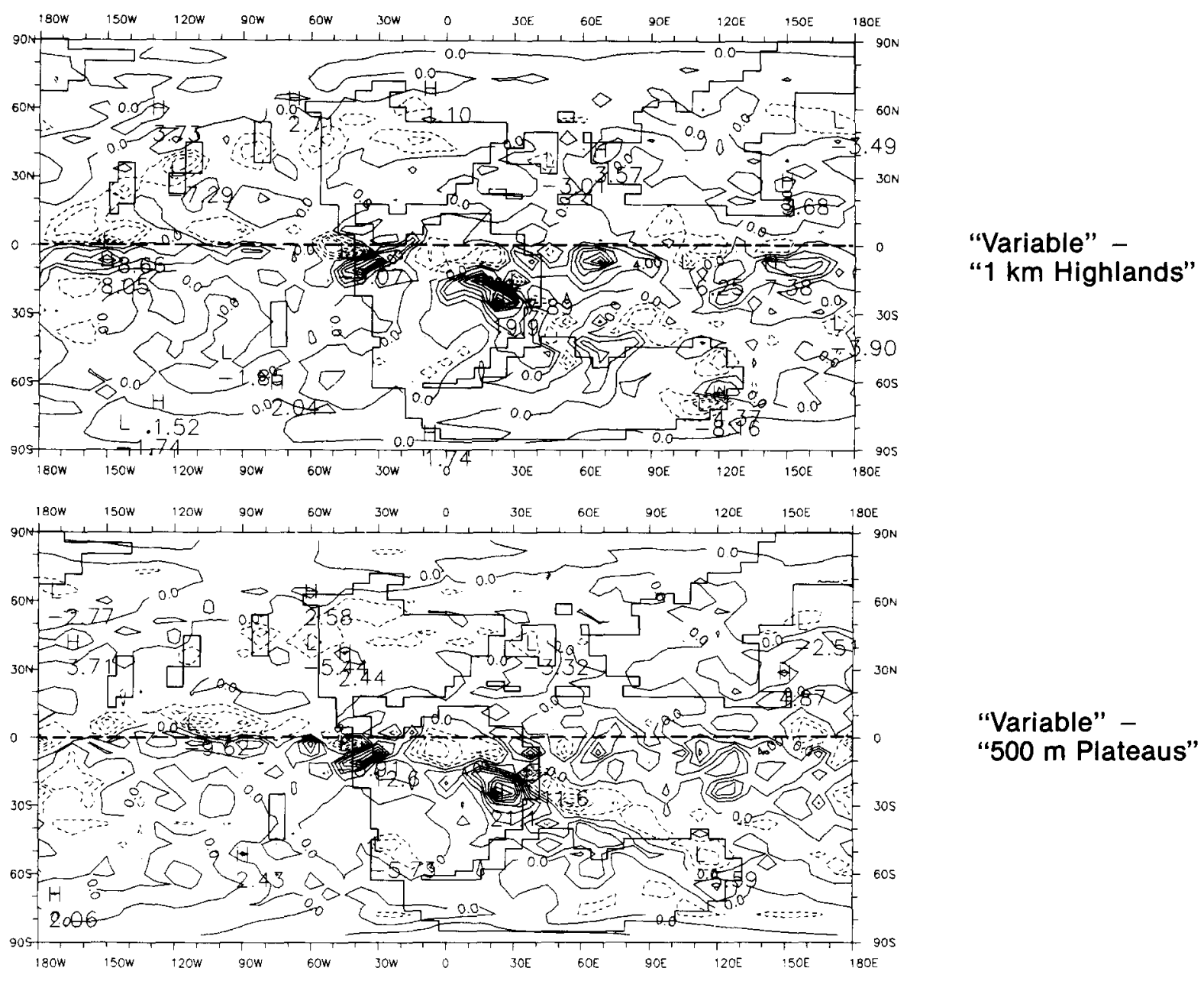

Fig. 17. Dec/Jan/Feb difference plots for precipitation $\left(\mathrm{mm} \mathrm{d}^{-1}\right)$ between the "variable" minus "1 km highlands" and "variable" minus " $500 \mathrm{~m}$ plateaus". $\mathrm{CI}=2 \mathrm{~mm} \mathrm{~d}-1$. Dashed contours represent negative values. See Fig. 3 for explanation.

tion in the low latitudes, with paleotopography contributing typical orographic effects (e.g., rain shadows) relating to the location and quantity of rainfall. Rain shadows are best developed in the winter hemispheres of the "variable" case (e.g. western side of the Asian range). Changes in precipitation associated with the orographically enhanced monsoon in southeastern Asia dramatically show the effects of paleotopography (Figs. 16 and 18). This example shows the importance of the orientation of mountain ranges and how paleotopography strongly influences the volume and extent of associated rainfall (Figs. 15-18). Similar, though weaker correlations, occur in the JJA precipitation related to the North American monsoonal and easterly circulation (Figs. 16 and 18). This is seen also in the northwestern North American JJA precipitation center forced by the Sierra Nevada. In contrast, areas for which precipitation is not sensitive to altered paleotopography include Australia and the margins of India and Antarctica.

\section{Latent heat}

The latent heat difference plots compare the "variable" with the other two cases (Fig. 19). In these plots, some high values coincide with regions where precipitation has decreased in the " $1 \mathrm{~km}$ highlands" and "500 $\mathrm{m}$ plateaus" cases relative to 


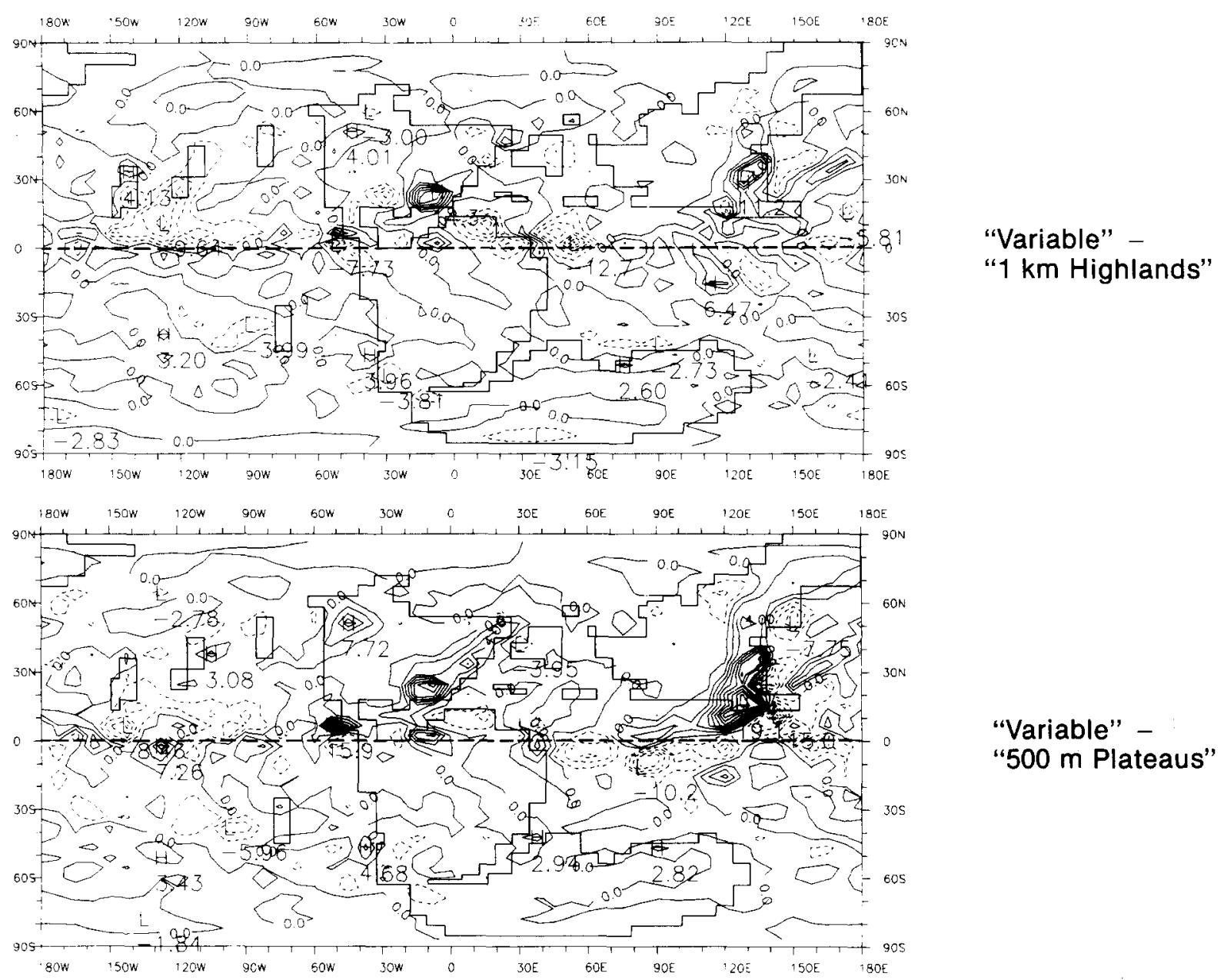

Fig. 18. June/July/Aug difference plots for precipitation $\left(\mathrm{mm} \mathrm{d}^{-1}\right)$ between the "variable" minus " $1 \mathrm{~km}$ highlands" and "variable" minus " $500 \mathrm{~m}$ plateaus". $\mathrm{CI}=2 \mathrm{~mm} \mathrm{~d}^{-1}$. Dashed contours represent negative values. See Fig. 3 for explanation.

the "variable" case (Fig. 10). Three prominent high centers coincide with diminished precipitation rates related to changed orography in the Sierra Nevada, Appalachian, and eastern Asian ranges (Fig. 19). These mountain regions also possess cooler surface temperatures due to lapse rate in the "variable" case as shown by the JJA temperature maps (Fig. 8) and difference plots (Fig. 10). This suggests a causal relationship between the regional heating in the " $1 \mathrm{~km}$ highlands" or " $500 \mathrm{~m}$ plateaus" cases (Fig. 8); less or no paleotopographically forced precipitation (Fig. 16) with attendant loss of radiative evaporation; and a positive latent heat flux difference (Fig. 19).

The change in latent heat flux is caused by two factors. First, because of lowered elevations in the
"1 km highlands" and "500 m plateaus" cases, the surface will be at, a lower position on the lapse rate curve $\left(5-10^{\circ} \mathrm{C}\right.$ increase per $1 \mathrm{~km}$ of descent). Lowering elevations will warm the land surface simply by this effect. Second, the orographicallyrelated precipitation increase in the "variable" case results in more moisture available for evaporation. Therefore, the "variable" case is more susceptible to evaporative cooling. Thus, land surface temperatures (LST), a well-utilized parameter by paleoclimate modelers, are intimately tied to the paleotopography on regional scales. That relationship alone in this sensitivity study results in a maximum JJA LST warming of $\sim 17^{\circ} \mathrm{C}$ and $\sim 24^{\circ} \mathrm{C}$ in the " $1 \mathrm{~km}$ highlands" and "500 m plateaus" cases respectively where orographically 


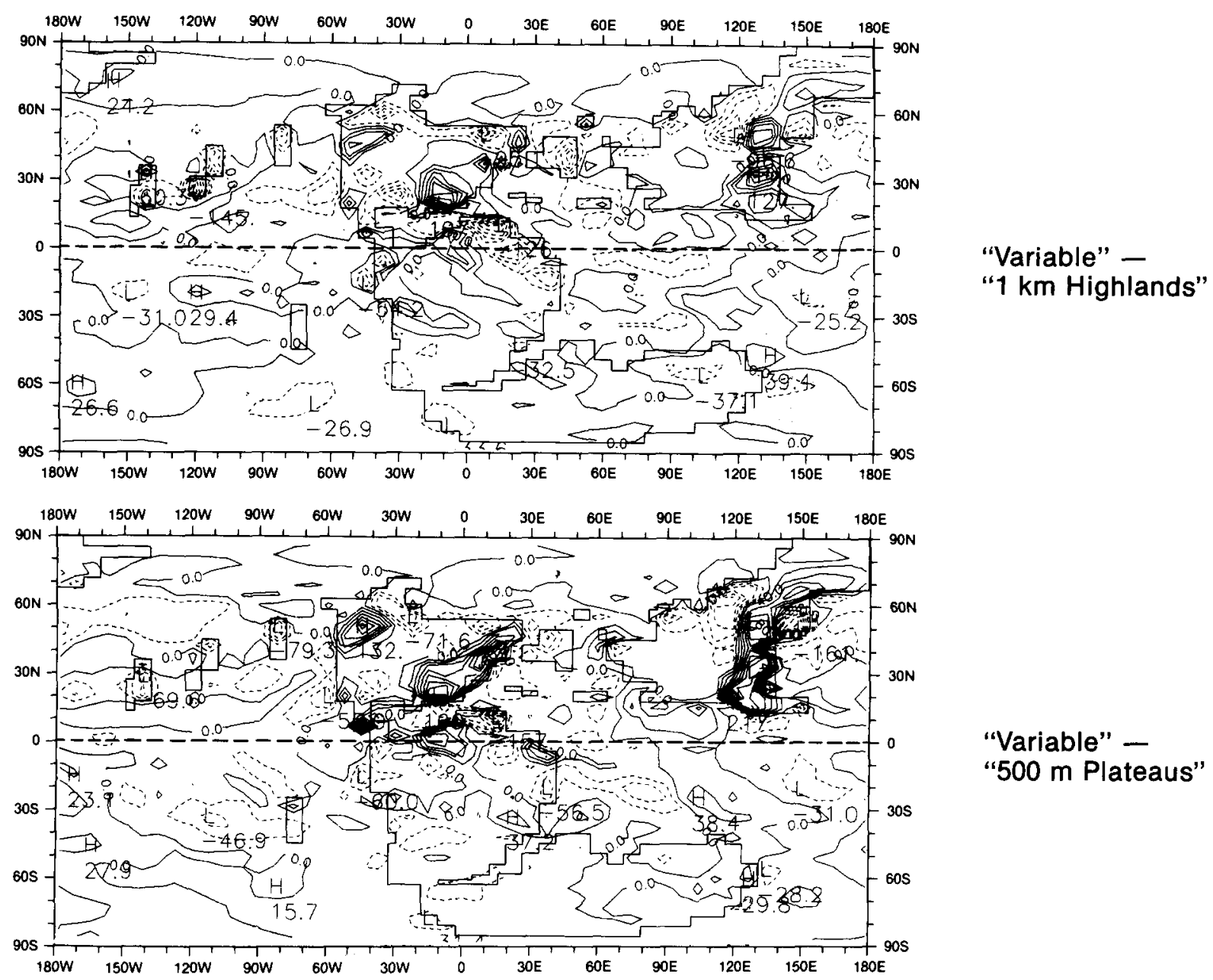

Fig. 19. June/July/Aug difference plots for latent heat flux $\left(\mathrm{W} \mathrm{m}^{-2}\right)$ between the "variable" minus " $1 \mathrm{~km}$ highlands" and the "variable" minus " $500 \mathrm{~m}$ plateaus". $\mathrm{CI}=20 \mathrm{~W} \mathrm{~m}^{-2}$. See Fig. 3 for explanation.

forced precipitation in the eastern Asia range is an important process (Fig. 10). In contrast, where the process is not an important factor, such as with the high latitude mountains of southern Gondwana, little LST change occurs in either season (Figs. 9 and 10).

\section{Summary and discussion}

Comparison of three Late Jurassic simulations, each with the same paleogeography and $\mathrm{CO}_{2}$ factor, but with differing paleotopography ("variable", "1 km highlands", and "500 m plateaus") yields the following observations.

The "variable" simulation possesses more com- plex thermal patterns over land than the other two. As paleotopographic contrasts are reduced, the summer temperature isotherms over the continents develop a concentric pattern, whereas the winter patterns are zonal, indicating a greater influence of continentality.

The oceans exhibit zonal SST patterns in both seasons. As paleotopographic contrasts decrease from the "variable" to the " $500 \mathrm{~m}$ plateaus" cases, the temperature patterns become more zonal. SST of the high latitude oceans warm with decreasing relief. The warmer SST's restrict sea ice extent and thickness (Part I). The continents are generally warmer overall, but the extremes are similar among cases. 
Seasonally, temperature trends in the DJF season for the three cases show: a largely zonal pattern for the isotherms across the N.H.; temperatures along the periphery of the S.H. continents reflect marine influence and warm toward the interior; the more simplified the paleotopography is in the S.H., the more concentric is the isotherm pattern but with a steeper gradient along the continental margins; and the oceans warm as the paleotopography becomes more simplified with the significant changes occurring poleward of $50^{\circ}$ (Figs. 7 and 9). Temperature trends in the JJA season for the three cases show: the equatorial ocean is virtually without change; the $0^{\circ}$ SST isotherm progressively migrates poleward in the S.H. with simpler paleotopography; the low $(1 \mathrm{~km})$ topography of Gondwana does not force interior temperatures as the isotherms show little variation between the " 500 m plateaus" case and the other two (Figs. 8 and 10).

Sea level pressure and surface wind patterns in the winter hemispheres trend toward more simplified zonal circulation as paleotopographic contrasts decrease with the simplest pattern occurring in the " $500 \mathrm{~m}$ plateaus" simulation. This is common to both hemispheres despite dissimilar paleogeographies. In contrast, the summer circulation patterns in both hemispheres, while simplified, remain dominated by paleogeography, irrespective of paleotopography.

The locations of land masses influence precipitation. The rate and areal extent of orographically forced precipitation are influenced strongly by paleotopography. Our results further support the contention that precipitation response is strongly influenced by other paleoclimate feedbacks.

The jet stream pathways in both hemispheres, and resulting mid-latitude storm tracks, become simplified and linear without the effects of paleotopography.

\section{Conclusions}

In conclusion, sensitivity tests comparing three simulations with the same paleogeography and paleoatmospheric concentration of $\mathrm{CO}_{2}$ (1120 ppm), but differing land elevations, show paleotopography is an important boundary condi- tion. However, in terms of influencing results, the effects of paleotopography upon model-produced climate are not always predictable.

Comparison of the "variable" case to the " $1 \mathrm{~km}$ highlands" and "500 m plateaus" cases shows that simplified paleotopography produces simplified global circulation.

Orographically forced circulation patterns, precipitation, and other climate-driven processes are modified when paleotopography is simplistic or ignored. The effects of paleotopography upon the paleoclimate are neither cumulative nor necessarily proportional to changing elevations. The results shown here demonstrate an interplay between orography, effects of continent size, and land-sea thermal differences. Thus, paleotopographic variation must be considered important in its influence upon the paleoclimate of any geologic time interval and must be incorporated into simulations.

The location and height of mountain ranges influence each investigated parameter. Further, paleotopography is linked as a driving force to atmospheric circulation, surface temperature, and the hydrologic cycle. Hence, to evaluate a simulation properly in terms of the preserved geologic record, we believe that paleotopography is on a par with the accuracy of the paleogeography employed.

Land and sea surface temperatures (LST, SST) generated in GCM simulations are employed by both modelers and other scientists of varying disciplines for various reasons. One of the more common usages is calibration of the model results with the preserved geologic record of floras, faunas, and/or environmentally sensitive sedimentary rocks (Sloan and Barron, (1992b). This study shows that because of lapse rate effects, the LST is intimately tied to the paleotopography on a regional scale. Thus, before using LSTs from a simulation with confidence, due consideration should be given to the authors' selection of both paleogeographic (which is obvious) and paleotopographic (which is far more subtle) boundary conditions.

As an additional observation, if only two end member paleotopographic specifications are employed, a logical extension might be that all paleotopographic specifications within those 
bounds would influence climate in a similar, intermediate fashion. In the Late Jurassic cases shown here we have found that such an assumption would be incorrect, except for a few basic responses such as the development of rain shadows. This suggests that all paleotopographic cases must be considered independently of one another and not simply interpolated between two simulations.

\section{Acknowledgements}

We thank S.R. Jacobson, C.A. Meyer, and two anonymous reviewers for providing many constructive suggestions that materially improved the manuscript. J.D. Koishor and J.L. Bube prepared the figures and B.A. Villegas typed the manuscript. We appreciate their help and attention to detail. The authors thank Chevron Oil Field Research Company for permission to publish this paper.

\section{References}

Barnola, J.M., Raynaud, D., Korotkevich, Y.S. and Lorius, C., 1987. Vostok ice core provides 160,000-year record of atmospheric $\mathrm{CO}_{2}$. Nature, 329: 408-414.

Barron, E.J. and Washington, W.M., 1984. The role of geographic variables in explaining paleoclimates: Results from Cretaceous climate model sensitivity studies. J. Geophys. Res., 84: 1267-1279.

Berner, R.A., 1990. Atmospheric carbon dioxide levels over Phanerozoic time. Science, 249: 1382-1386.

Bolin, B., 1950. On the influence of the Earth's orography on the general character of the westerlies. Tellus, 2: 184-195.

Budyko, M.I., Ronov, A.B. and Yanshin, A.L., 1985. Changes in the chemical composition of the atmosphere during the Phanerozoic. Int. Geol., 27: 423-433.

Hallam, A., 1985. A review of Mesozoic climates. J. Geol. Soc. London, 142: 433-445.

Harland, W.B., Armstrong, R.L., Cox, A.V., Craig, L.E., Smith, A.G. and Smith, D.G., 1990. Geologic Time Scale 1989. Cambridge Univ. Press.

Kasahara, A. and Washington, W.M., 1971. General circulation experiments with a six-layer NCAR model, including orography, cloudiness, and surface temperature calculations. J. Atmos. Sci., 28: 657-701.

Kuo, C., Lindberg, C. and Thompson, D.J., 1990. Coherence established between atmospheric carbon dioxide and global temperature. Nature, 343: 709-714.
Kutzbach, J.E., Guetter, P.J., Ruddiman, W. and Prell, W.L., 1989. Sensitivity of climate to late Cenozoic uplift in southern Asia and the American west: Numerical experiments. J. Geophys. Res., 94: 18,393-18,407.

Manabe, S. and Terpstra, T.B., 1974. The effects of mountains on the general circulation of the atmosphere as identified by numerical experiments. J. Atmos. Sci., 31: 3-42.

Moore, G.T., Hayashida, D.N., Ross, C.A. and Jacobson, S.R., 1992. The paleoclimate of the Kimmeridgian/Tithonian (Late Jurassic) world: I Results using a general circulation model. Palaeogeogr., Palaeoclimatol., Palaeoecol., 93: $113-150$.

Pearman, G.I., Etheridge, D., De Silva, F. and Fraser, P.J., 1986. Evidence of changing concentrations of atmospheric $\mathrm{CO}_{2}, \mathrm{~N}_{2} \mathrm{O}$, and $\mathrm{CH}_{4}$ from air bubbles in Antarctic ice. Nature, 320: 248-250.

Rind, D., 1988. Dependence of warm and cold climate depiction on climate model resolution. J. Climate, 1: 965-997.

Ross, C.A. and Ross, J.R.P., 1983. Late Paleozoic accreted terranes of western North America. In: C.H. Stevens (Editor), Pre-Jurassic Rocks in Western North American Suspect Terranes. Pac. Sect. SEPM, Los Angeles, CA, pp. 7-22.

Ross, C.A., Moore, G.T. and Hayashida, D.N., 1992. Late Jurassic paleoclimate simulation-Paleoecological implications for ammonoid provinciality. Palaios, in press.

Rowley, D.B., 1992. Preliminary Jurassic reconstructions of the Circum-Pacific region. In: G.E.G. Westermann (Editor), The Jurassic of the Circum-Pacific, IGCT Project 171. Cambridge Univ. Press, pp. 15-27.

Ruddiman, W.F, and Kutzbach, J.E, 1989. Forcing of late Cenozoic northern hemisphere climate by plateau uplift in southern Asia and the American west. J. Geophys. Res., 94: $18,409-18,427$.

Scotese, C.R., 1992. Atlas of Phanerozoic Plate Tectonic Reconstructions. Am. Geophys. Union, Washington, DC, in prep.

Sloan, L.C. and Barron, E.J., 1992a. Paleogene climatic evolution: A climate model investigation of the influence of continental elevation and sea surface temperature upon continental climate. In: D. Prothero (Editor), Eocene-Oligocene Climatic and Biotic Evolution. Princeton Univ. Press, Princeton, NJ, in press.

Sloan, L.C. and Barron, E.J., 1992b. A comparison of Eocene climate model results to quantified paleoclimatic interpretations. Palaeogeogr., Palaeoclimatol., Palaeoecol., in press.

Washington, W.M. and Meehl, G.A., 1984. Seasonal cycle experiment on the climate sensitivity due to a doubling of $\mathrm{CO}_{2}$ with an atmospheric general circulation model coupled to a simple mixed-layer ocean. J. Geophys. Res., 89: 94759503.

Ziegler, A.M., Scotese, C.R. and Barrett, S.F., 1983. Mesozoic and Cenozoic paleogeographic maps. In: P. Brosche and J. Sündermann (Editors), Tidal Friction and the Earth's Rotation II. Springer, Berlin, pp. 240-252. 